\title{
Violence and Social Repair: Rethinking the Contribution of Justice to Reconciliation
}

\author{
Laurel E. Fletcher* \\ Harvey M. Weinstein**
}

\begin{abstract}
Close relatives and friends are dead or missing. Homes lie in ruins. Property has been destroyed. With everybody experiencing trouble, severe privations and physical suffering, it is still something altogether different whether one retains a home and household goods or has been ruined by bombs; whether he sustained his suffering and losses in combat at the front, at home, or in a concentration camp; whether he was a hunted ... victim or one of those who, even though in fear, profited by the regime.... Men have come to the limits of humanity and returned home, unable to forget what really was... . The suffering differs in kind, and most people have sense only for their
\end{abstract}

* Laurel E. Fletcher is Acting Clinical Professor of Law, Associate Director of the International Human Rights Law Clinic, University of California, Berkeley School of Law (Boalt Hall); B.A., Brandeis University (1986); J.D., Harvard Law School (1990).

** Harvey M. Weinstein is Clinical Professor, School of Public Heath, Associate Director, Human Rights Center, University of California, Berkeley; B.Sc., McGill University (1963); MDCM, McGill University (1967); M.P.H., University of California, Berkeley (1994).

The order of authorship is alphabetical. Both authors contributed equally to this article. This article grew out of the authors' participation in Communities in Crisis: Justice, Accountability, and Social Reconstruction in Rwanda and Former Yugoslavia, principal investigators Eric Stover, Harvey Weinstein, and Michael Watts. This is an interdisciplinary, multi-institutional project initiated in 1998, and awarded by the John D. and Catherine T. MacArthur Foundation to the Human Rights Center at the University of California, Berkeley to examine the relationship between the pursuit of international justice and local approaches to social reconstruction in the aftermath of genocide in Rwanda and the former Yugoslavia. We gratefully acknowledge the support and insightful comments of Diane Marie Amann, Carolyn Patty Blum, Justice Richard R. Goldstone, Naomi Roht-Arriaza, Diane Orentlicher, and Eric Stover. Our gratitude to the Center for Social Justice at Boalt Hall, which provided a forum for presentation of an earlier draft of this article and to lan Haney-Lopez, Angela Harris, Nancy Lemon, Ayn Lowry, Rachel Moran, Stephen Rosenbaum, Marge Schultz, Jeff Selbin, Eleanor Swift, Charles Weisselberg, and Stephanie Wildman for their helpful comments. Many thanks to the research support from Katherine Zucca, Saša Madacki, Robin Appleberry, Ivana Jasmin Cingel, and Andrea Reggio, and for the invaluable assistance of Wiltrud Harms, the UN Documents Librarian at Boalt Hall. Our sincere appreciation for the tireless patience of Debra Krauss in preparing the manuscript. 
kind. Everyone tends to interpret great losses and trials as a sacrifice. But the possible interpretations of this sacrifice are so abysmally different that, at first, they divide people.

Karl Jaspers'

\section{INTRODUCTION}

In the last decade, there has been a burgeoning interest in the question of how countries recover from episodes of mass violence or gross human rights violations. ${ }^{2}$ This interest has focused on the concept of transitional justice, a term we use to describe the processes by which a state seeks to redress the violations of a prior regime. ${ }^{3}$ Despite the fact that military and political leaders who ordered or directed mass terror generally have evaded accountability for their deeds, justice-in the form of criminal trials-has

1. Karl Jaspers, The Question of German Guilt 20-21 (1947).

2. Scholars, journalists, and activists have examined the issue of how countries grapple with horrific and sustained periods of repression or mass violence from a variety of disciplines and perspectives. Some have looked at the ways that particular countries have been affected by political transformation and sought to grapple with the past. See Human Rights in Political Transitions: Gettrsburg to Bosnia (Carla Hesse \& Robert Post eds., 1999); Aryeh Neier, War Crimes: Brutality, Genocide, Terror, and the Struggle for Justice (1998); Michael. lgnatieff, The Warrior's Honor: Ethnic War and the Modern Conscience (1997); Tina Rosenberg, The Haunted Land: Facing Europe's Ghosts After Communism (1995). Others have focused on particular mechanisms countries have used to confront the past, including truth commissions: Priscilla B. Hayner, Unspeakable Truths: Confronting State TERror AND Atrocity (2000) (a study of twenty-one truth commissions world-wide); and domestic criminal trials, Mark Osiel, Mass Atrocity, Collective Memory, and the Law (1997) (the author identifies and examines problems confronting a nation's use of criminal trials to forge a collective memory about the past based on the experiences of Germany, Japan, France, Israel, and Argentina). Still others have offered theoretical frameworks for understanding the role of law in assisting in political and social transformation. See Rutı G. Teitel, Transitional Justice (2000); Martha Minow, Between Vengeance and Forgiveness: Facing History after Genocide and Mass Violence (1998); Naomi Roht-Arriaza, Impunity and Human Rights in International Law and Practice (1995). The three-volume work by Neil Kritz, addresses conceptual problems confronting societies in transition as well as providing surveys of twenty-one countries in Europe, Asia, Latin America, and Africa and their efforts during the past fifty years to address their violent and repressive pasts. Transimional Justice (Neil J. Kritz ed., 1995).

3. Not all those who write about accountability for war crimes and gross human rights violations in the aftermath of mass violence or state repression expressly employ the term "transitional justice." Some conceptualize this issue as a choice between whether a country seeks to remember the past or forget the prior horrors in order to restore social harmony. See, e.g., HaYner, supra note 2, at 1; Robert Post \& Carla Hesse, Introduction, in Human Rights in Political Transitions, supra note 2, at 15; Minow, supra note 2, at 2. Nevertheless what defines the literature on transitional justice is its central concern with the question, variously phrased: "How should a society come to terms with a violent past?" See, e.g., TeItel, supra note 2, at 3; OsIel, supra note 2, at 2; Rosenberc, supra note 2 , at xiv. Thus, for purposes of our analysis, we define transitional justice literature as works that seek to address this challenge. 
been the rallying cry of many who seek to repair the injury individuals and communities have sustained as a result of these heinous acts. ${ }^{4}$ As dictatorships and repressive regimes fell in Latin America in the 1980s and 1990s, human rights scholars and advocates pressed states to initiate domestic criminal proceedings against the notorious intellectual authors of mass terror and their faithful subordinates. ${ }^{5}$ However, the fragile democracies, weak judiciaries, and amnesty laws made domestic trials difficult to institute. $^{6}$

Further, the character of war has shifted from inter- to intra-state conflict since World War $11 .^{7}$ These wars reflect intense competition for power and

4. Human rights organizations have spear-headed international advocacy campaigns to hold human rights abusers and war criminals accountable for their crimes. In particular, Human Rights Watch, a nongovernmental organization (NGO) founded in the United States has been a leader in this regard. As noted by one of its founders and former executive director, Aryeh Neier, the fight against impunity has been "central to the international human rights movement in recent years." Neler, supra note 2, at xii-xiii. In particular, Neier notes that the conflicts in Bosnia and Rwanda underscored the need for accountability, since the "truth" about the atrocities committed generally was not in dispute and a truth commission for Bosnia would have been a "meaningless gesture." Thus the quest for "justice" displaced the traditional pursuit for "truth" as the rallying cry for the human rights movement. Aryeh Neier, Rethinking Truth, Justice and Guilt after Bosnia and Rwanda, in Human Rights in Political Transitions, supra note 2, at 42. Interest in anti-impunity mechanisms also has generated interest and debate within legal academies. See, e.g., Conference, War Crimes Tribunals: The Record and the Prospects, 13 Am. U. INT'L L. Rev. 1541 (1998); Symposium, War Crimes and War Crimes Tribunals: Past, Present, and Future, 3 Hofstra L. \& Pol'r SYmp. 1 (1999); Genocide, War Crimes, and Crimes Against Humanity, 23 Fordham INT'L L.J. 1 (1999); Symposium, Accountability for International Crime and Serious Violations of Fundamental Human Rights, 59 LAw \& Contemp. Probs. 1 (1996); Symposium, Law and Lustration: Righting the Wrongs of the Past, 20 L. \& Soc. INQUiRY 1 (1995).

5. For a review of measures several Latin American countries undertook to achieve justice for victims of prior military regimes, see ROHT-ArRIAZA, supra note 2, at 147-217 (case studies on Chile, Argentina, Haiti, and El Salvador); see also Transitional Justice, supra note 2 (Volume II of the work is devoted to country studies). For some of the first legal analyses for the basis for domestic and international prosecutions, see Naomi RohtArriaza, State Responsibility to Investigate and Prosecute Grave Human Rights Violations in International Law, 78 CaL. L. Rev. 451 (1990); Diane Orentlicher, Settling Accounts: The Duty to Prosecute Human Rights Violations of a Prior Regime, 100 YALE L.J. 2537 (1991).

6. The resistance from the military to criminal trials which countries like Argentina faced resulted in the government enacting laws to shield virtually all military perpetrators from criminal sanctions. Thus, the debate among human rights scholars and activists centered on whether stability in these countries necessarily must be purchased at the expense of the victims of the prior regime. See Orentlicher, supra note 5, at 2539-46. For an examination of the treatment of amnesty laws by judiciaries in numerous Latin American and African countries, see Naomi Roht-Arriaza \& Lauren Gibson, The Developing Jurisprudence on Amnesty, 20 Hum. RTs. Q. 843 (1998).

7. Richard M. Garfield \& Alfred Neugut, The Human Consequences of War, in WAR AND Public Health 27, 33 (Barry S. Levy \& Victor W. Sider eds., 1997); Derek Summerfield, Network Paper 14, The Impact of War and Atrocity on Civilian Populations: Basic Principles for NGO Interventions and a Critique of Psychosocial Trauma Projects 1-5 (1996). 
wealth among groups struggling for supremacy. Often characterized as racially, ethnically, or tribally motivated, one commonality among these conflicts is that warring forces target civilian populations, particularly women and children, and cause massive destruction of infrastructure. ${ }^{8}$ Mass violence results in the breakdown of societal structures-social and economic institutions, and networks of familial and intimate relationships that provide the foundation for a functioning community. ${ }^{9}$ Indiscriminate and episodic violence occurs at random and affects people at a neighborhood level. Even where the violence is centrally planned (as in Bosnia-Herzegovina or Rwanda), ${ }^{10}$ the collaboration of paramilitary with military units produces acts of violence and cruelty that are designed not only to kill but to terrorize and destroy the basis of community life. ${ }^{11}$ Neighbor-on-neighbor violence is

8. See Carnegie Commission on Preventinc Deadly Conflict, Preventing Deadly Conflict: Final REPORT 25-30 (1997). Civilian deaths have increased from 14 percent to 90 percent of all war-related deaths from 1914 to 1997 . Summerfielo, supra note 7 , at 1-5.

9. Summerfield, supra note 7, at 5-9. The nature and duration of conflicts varies widely, the characteristics of which will determine which and how particular societal structures are affected. For example, in the "dirty wars" of Chile and Argentina armed opposition was not a significant feature. See Argentine National Commission on the Disappeared, Nunca Más: The Report of the Argentine National. Commission on the Disappeared xiv (1986); National Commission on Truth and Reconciliation, Report of the Chilean National Commission on Truth AND RECONCILIAIION Xxv, 679-86 (1993). The physical infrastructure of the country was not destroyed by the targeting of suspected civilian "subversives" so much as the social fabric. On the other hand, protracted armed conflicts in the Balkans, Cambodia, El Salvador, Guatemala, Rwanda, and Sierra Leone have taken a huge toll on the physical, economic and social infrastructures of those countries. South Africa is a unique example, in that the apartheid system by design created and maintained a racial system of preferential development enforced by a brutal police force that targeted for torture and murder opposition leaders to the regime. See Truth and ReCONCILIATION Commission of South Africa, 5 Truth and Reconciliation Commission of South Africa Report 212-27 (1999 ed.).

10. See Jasminka Udovicki \& Ivan Torov, The Interlude: 1980-1990, in BURN THIS HOUSE: THE Makinc AND UnmakinG OF YugOSLAVIA, 80-106 Uasminka Udovicki \& James Ridgeway eds., 1997). In this edited volume, the history and fall of Yugoslavia is well documented by Slavic writers, historians, and politicians. In particular, the role of Presidents Milosevic and Tudjman as architects of the division of the Federal Socialist Republic of Yugoslavia is described. $/ d$. at 88-97. See generally United Nations Security Council, Letter dated 24 May 1994 from the Secretary-General to the President of the Security Council (transmitting Final Report of the Commission of Experts Established Pursuant to Security Council Resolution 780, at II II 310-1841 (1992)) U.N. Doc. S/1994/674 (1994); Human Rights Watch, Leave None to Tell the Story: Genocide in Rwanda (1999). See also Samantha Power, Bystanders to Genocide: Why the United States Let the Rwandan Tragedy Happen, AtLantic Monthly, Sept. 2001, at 88 ("The signs of militarization in Rwanda were so widespread that even without much of an intelligence-gathering capacity, [Canadian General Romeol Dallaire [head of UN presence in Rwanda] was able to learn of the extremists' sinister intentions.").

11. Chuck Sudetic chronicles the brutal effects of this strategy through the life of a Bosniak (Bosnian Muslim) family that was forced to leave their ancestral home in eastern Bosnia by Bosnian Serb and Serb paramilitaries. Chuck Sudetic, Blood and Venceance: One Family's STORY OF THE WAR IN BOSNIA (1998). For a similarly chilling account of how civilians were organized to kill their Tutsi and moderate Hutu neighbors during the Rwandan geno- 
characteristic of this form of aggression as seemingly peaceful community members are swept up in the inexorable process of killing. ${ }^{12}$ Thus, human suffering at a communal level is a shared feature of contemporary conflict.

Yet, with the exception of the Nuremberg and Tokyo Tribunals, there have been no international mechanisms for accountability until the recent ad hoc criminal tribunals for the former Yugoslavia and Rwanda. ${ }^{13}$ Drawing on the Latin American context, international criminal trials have become a significant response to mass violence, ${ }^{14}$ and this trend is strengthened as the International Criminal Court ("ICC") comes closer to a creation. ${ }^{15}$

cide, see Philip Gourevitch, We Wish to Inform You That Tomorrow We Will be Killed with Our Families: Stories from Rwanda (1998).

12. See Gourevitch, supra note 11; Peter MaAss, Love Thy Neighbor: A Story of War (1996). This type of violence, though, is not "spontaneous," but rather enabled by extensive planning and coordination. For example, in Rwanda there was extensive coordination among political, military, and paramilitary as well as religious leaders to plan and carry out the genocide. See Human Richts Watch, supra note 10, at 226-41.

13. The ad hoc criminal tribunal for the former Yugoslavia was created by the United Nations Security Council in May 1993, S.C. Res. 827, U.N. SCOR, 48th Sess., 3217th mtg., U.N. Doc. S/RES/827 (1993) [hereinafter ICTY Statute], and the tribunal for Rwanda was created in 1994, S.C. Res. 955, U.N. SCOR, 49th Sess., 3453rd mtg., Annex, U.N. Doc. S/RES/955 (1994) [hereinafter ICTR Statute].

14. This trend is reflected in the proposals to establish trials to prosecute alleged war criminals in other countries. For example, in Sierra Leone, a tribunal staffed jointly by the United Nations and judges and officers appointed by Sierra Leone has been established. Agreement between the United States and the Government of Sierra Leone on the Establishment of a Special Court for Sierra Leone, 16 Jan 2002, U.N.-Sierra Leone, United Nations Security Council, Letter Dated 6 March 2002 From the Secretary-General Addressed to the President of the Security Council, at 17, U.N. Doc. 2/2002/246 (2002), available at <http//www.un.org/Docs/se/letters/2002/2463.pdf> (last visited 15 Apr. 2002); in Cambodia, a special domestic court to prosecute former Khmer Rouge leaders was proposed to operate with involvement of the United Nations, but negotiations have been halted. U.N. Ends Negotiations with Cambodia for Proposed Court to Try Former Khmer, Today's Feature, United Nations Radio News, available at <http//www.un.org/av/radio/new/2002/feb/script02021100.htm> (last visited 15 Apr. 2002). Each of these tribunals would be composed of both domestic and international staff to retain both international jurisdiction and domestic participation. Report of the Secretary-General on the establishment of a Special Court for Sierra Leone, at 11 9, U.N. Doc. $\$ / 2000 / 915$ (2000). National truth and reconciliation commissions also are contemplated for Sierra Leone and East Timor, suggesting that these institutions are not necessarily mutually exclusive mechanisms to reckon with mass violence. Report of the Secretary-General on the Establishment of a Special Court for Sierra Leone, at II 9, U.N. Doc. S/2000/915 (2000); see Report of the Secretary-General on the United Nations Transitional Administration in East Timor, at II 40, U.N. Doc. S/2001/983 (2001); see III.B.2.c. While the conflict in East Timor had international repercussions, the anticipated accountability mechanism will be national in nature. See Report of the SecretaryGeneral on the United Nations Transitional Administration in East Timor, at 11 31, U.N. Doc. S/2001/983 (2001) (President Megawati Soekarnoputri has established a national tribunal to prosecute perpetrators of gross human rights violations in East Timor, the scope of which has been criticized because the court would have jurisdiction only for crimes committed during April-September 1999 in particular districts).

15. The Rome Statute of the International Criminal Court was adopted on 17 July 1998, U.N. Doc. AVCONF.183/9 (1998), corrected 10 Nov. 1998, 12 July 1999, 30 Nov. 
Thus, the predominant mechanism to respond to mass violence focuses on individual perpetrators of war crimes and other serious violations of international law. Frequently, advocates for this model suggest that international trials may be the single most appropriate response to communal violence. While transitional justice scholars recognize that judicial and truth-seeking mechanisms constitute one important component of a response to mass violence, events of the last decade suggest that many diplomats and human rights advocates conceive of international criminal trials as the centerpiece of social repair. ${ }^{16}$ Indeed, "social reconciliation" has

1999, and 8 May 2000, available at <http://www.un.org/law/icc/statute/romefra.htm> (visited 15 Apr. 2002) [hereinafter ICC statute]. On 11 Apr. 2002 the ICC formally was established when six countries ratified the treaty, bringing the total number of ratifications over the required sixty. United Nations, International Criminal Court Will Enter Into Force on 1 July 2002, As Ten States Deposit Ratification Instruments at Headquarters, Preparatory Commission for International Criminal Court, 35th Meeting (AM), L/3000 (11 Apr. 2002) available at <http://www.un.org/News/Press/docs/2002/ L3000.doc.htm> (last visited 15 Apr. 2002).

16. This sentiment is reflected in the statute of the ICC, which links prosecution of grave crimes with "peace, security and well-being of the world," in general and to ending impunity for and ensuring prevention of such crimes. ICC statute, preamble, supra note 15. Further, the connection between prosecutions and social reconstruction is explicit in statements by diplomats. See United Nations, Uniteo Nations Diplomatic Conference of Plenipotentiaries on the Establishment of an International Criminal Court, Summary Record of the 4th Plenary Meting at 13, U.N. Doc. A/CONF.183/SR.4 (1998) (Soren JessenPeterson, the UN Assistant High Commissioner for Refugees stated, "Any permanent court could help prevent future atrocities and also promote reconciliation in societies emerging from conflict."); United Nations, United Nations Diplomatic Conferencf of Plenifotentiakies on the Establishment of an International Criminal Court, Summary Record of the 2nd Plenary Meeting at 5, U.N. Doc. A/CONF.183/SR.2 (15 June 1998), available at <http:/www.un.org/icc/speeches/615uk.htm> (visited 25 Mar. 2002) (Tony Lloyd, British Minister of State speaking on behalf of the European Union, noted that a permanent Court would make the world a more peaceful place "because the knowledge that justice is being done may help victims to put the past behind them and encourage all the parties to participate in a process of reconciliation."); The Honourable Lloyd Axworthy, Minister of Foreign Affairs, Canada, Address at United Nations Diplomatic Conference of Plenipotentiaries on the Establishment of an International Criminal Court (15 June 1998), available at $\langle\mathrm{http} / / \mathrm{www}$.un.org/icc/speeches/615can.htm> (visited 25 Mar. 2002) (Axworthy remarked, "By isolating and stigmatizing those who commit war crimes or genocide, and removing them from the community, it will help to end cycles of impunity and retribution. Without justice, there is no reconciliation, and without reconciliation, no peace.") In addition, a group of international jurists recently has published principles to encourage countries to exercise universal jurisdiction-the international legal doctrine that allows countries to prosecute violators of the most egregious international crimes-and is another example of the attention to criminal accountability as an essential component of an international response to mass violence. Princeton Project on Universal Jurisdiction, The Princeton Principles on Universal Jurisdiction (2001). See also M. Cherif Bassiouni, The Commission of Experts Established pursuant to Security Council Resolution 780: Investigating Violations of International Humanitarian Law in the Former Yugoslavia, 5 CRIM. L. F. 279, 339 (1994); Peter Burns, An International Criminal Tribunal: The Difficult Union of Principle and Politics, 5 CRIM. L. F. 341, 344, 374 (1994). 
become a mandate of these proceedings. ${ }^{17}$ While international trials are laudable, assigning accountability for mass atrocities to individuals has certain limitations. This article explores certain of these limitations and offers a new model to understand the contribution of trials to social reconstruction.

The focus of trials on the individuals responsible for ordering or carrying out acts of mass violence leaves three categories of persons and groups largely untouched: (1) unindicted perpetrators including community members who directly or indirectly profited from the event; (2) states outside the area of conflict that may have contributed to the outbreak of violence by their acts or omissions; and, (3) the bystanders who did not actively participate in violence, but who also did not actively intervene to stop the horrors. With regard to the first category, the sheer numbers of those who engaged in criminal acts overwhelms the capacity of domestic and international justice systems. ${ }^{18}$ Selectivity of prosecution will remain an issue with which communities must grapple. In addition, trials have focused on the officials who controlled the regime and, to a lesser extent, military or paramilitary personnel who carried out atrocities.

A recent example of this second category is the failure of the international community to intervene despite clear indications that atrocities were to be carried out in Rwanda and that the Bosnian Serb forces were about to overrun the UN-designated "safe haven" of Srebrenica in Bosnia. This raises

17. The statute for the Rwanda tribunal explicitly states that through criminal trials the court "would contribute to the process of national reconciliation." ICTR Statute, supra note 13, preamble, and the ICTY Statute states that its work is aimed to "bring justice" to the perpetrators and "contribute to the restoration and maintenance of peace." ICTY Statute, supra note 13, preamble. This is an expansion of the mandate of tribunals. The goals of the Nuremberg and Tokyo trials were punishment. See Opening Statement of Justice Jackson (21 Nov. 1945) in 2 Trial of the Major War Criminals Before the International Military Tribunal 98-99 (1947); Telford Taylor, The Anatomy of the Nuremberg Trials 85-90 (1993).

18. For example, the Security Council confronted this issue in its recommendation that the proposed statute for the ad hoc tribunal for Sierra Leone establish jurisdiction of the court to try those "who bear the greatest responsibility for the commission of the crimes." See Report of the Secretary-General on the Establishment of a Special Court for Sierra Leone, supra note 14, II 29. The statutes of the ICTY and ICTR contain no such limitation, however, their institutional limits on trials are readily apparent. While arguably hundreds, if not thousands, planned and directed the mass atrocities in Bosnia and Rwanda to date, the ICTY has conducted thirty-two trials. United Nations, Fact Sheet on ICTY Proceedings, available at $\langle$ http:/www.un.org/icty/glance/procfact-e.htm> (visited 24 Apr. 2002). The ICTR has convicted eight detainees. United Nations, International Criminal Tribunal for Rwanda, Detention of Suspects and Imprisonment of Convicted Persons, available at <http:/www.ictr.org/ENGLISH/factsheets/7.htm> (last visited $24 \mathrm{Apr}$. 2002). A modest record, particularly compared to the aspirations for these trials to hold even the principal perpetrators accountable. 
the question of whether the UN is liable under international law for the ensuing carnage..$^{19}$ However, this article leaves aside these topics for further discussion. Instead, we focus our attention on two important groups of participants in mass violence which lie beyond the reach of trials: (1) those who, swept along by group emotion or solidarity, participate at the margins - looting, taunting, or profiting from the misfortune of their neighbors-and (2) the so-called "innocent bystanders," those who did nothing to stop or mitigate the atrocities.

Trials do not address the complicity of those who stood by or cheered a vicious leader or who elected a war criminal to represent them. Currently, there are no mechanisms to respond to the ways in which bystanders are implicated in the establishment and maintenance of societal structures that facilitate the onset and implementation of mass violence. Thus, we question whether individualized guilt may contribute to a myth of collective innocence. Criminal trials single out intellectual authors and actual perpetrators of atrocities while leaving to broader initiatives in rule of law, humanitarian assistance, democracy building, and economic development the task of resuscitating a "sick society." We argue that such an approach that does not integrate trials with these other capacity-building measures is insufficient to attend to social repair. If we do not comprehend the processes of civil destruction in a broader, ecological context, how can we identify and address the crucial aspects of civic reconstruction? In this article, we offer an ecological model to understand social breakdown and to identify the critical elements of social repair. Although this model incorporates criminal trials as one component, we extend consideration of the processes of social repair into multiple dimensions.

In section II, we begin with a review of the prevailing justifications for war crimes trials. We critique these justifications with respect to the theoretical limitations of these proceedings as vehicles for social repair. Although billed by many advocates as critical to enable societies to recover from mass violence, trials as justice are not the cure that all segments critical to rebuilding seek. Our critique is informed by the findings of a study on the attitudes of judges and prosecutors in Bosnia to war crimes trials and their views on the efficacy of domestic and international trials in social reconstruction. ${ }^{20}$ One of the most striking findings of the study was that

19. See Ruti Teitel, Bringing the Messiah Through the Law, in Human RIGHTS IN Poumical Transitions, supra note 2 , at 185-86. For a thorough account of the extent to which governments and the United Nations were aware of the planning for the genocide inside

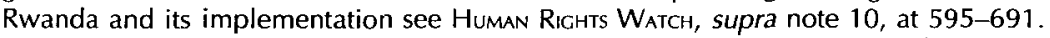

20. Human Rights Center, International Human Rights Law Clinic, Centre for Human Rights, Justice, Accountability and Social Reconstruction: An Interview Study of Bosnian Judges and Prosecutors, 18 BERK. J. INT'L L. 102 (2000) [hereinafter Interview Study]. This 
universally individuals identified their national group as victims. ${ }^{21}$ Respondents adhered to the principle of individual accountability and rejected the concept of collective guilt. ${ }^{22}$ They looked to war crimes trials to reaffirm the victimization of their own national group. ${ }^{23}$ There was no evidence that respondents acknowledged that war crimes were committed in their name.

We aver that there is a collective nature to mass violence that challenges the validity of the construct of "the innocent bystander": the individual who was neither a victim nor committed a crime, nor took up arms. In section III of this article, we review the literature on collective action by examining the contributions of social psychology to understanding group behavior. This literature suggests that individual action or inaction is influenced profoundly by social context, particularly in situations of conflict. This leads us to question whether the consequences of collective violence effectively can be addressed without attending to the collective as a unit of analysis.

Thus, in section IV, we look at the phenomenon of social breakdown and social reconstruction. We develop a heuristic to depict the degeneration of the collective and attendant consequences. In addition, we propose an ecological model of social reconstruction that considers a spectrum of interventions that includes, but is broader than, criminal trials. This approach, grounded in empirical studies of the actions of individuals in group contexts as well as some current perceptions of the contribution of criminal trials to social reconstruction, contributes to a fuller understanding of the complex processes that underlie the rebuilding of fragmented societies.

In the final section, we allow the ecological model to inform a series of new questions that reframe the goals of transitional justice and social repair. We offer these ideas to generate further discussion and research across disciplines. The problems of mass violence exceed the expertise of any one profession. Therefore, we present a model that offers a modest beginning for comprehensive and collaborative problem solving in an area fraught with complexity.

study is part of the Communities in Crisis project undertaken by the Human Rights Center at the University of California, Berkeley. The report is the first of a series of studies initiated by the Human Rights Center to examine the factors that contribute to social reconstruction in the aftermath of mass violence. The Interview Study focused on judges and prosecutors with jurisdiction for domestic war crimes trials since the ICTY will prosecute only a fraction of potential defendants. Id. at 109. Therefore mass accountability for war crimes, if it is to occur, will take place in the courts of Bosnia and Herzegovina rather than in The Hague. This study, while of a representative sample, is limited in size. For a fuller description of the study and its strengths and limitations, please consult the full report.

21. See id. at $127-36,147$.

22. Id.

23. Id. at $147-48$. 


\section{CONVENTIONAL CONCEPTIONS OF TRIALS AS A RESPONSE TO WAR CRIMES AND GROSS HUMAN RIGHTS VIOLATIONS}

\section{A. The Legal Paradigm}

Since the Universal Declaration of Human Rights in 1948, the development of human rights norms, institutions and enforcement mechanisms has been driven by the international legal community. ${ }^{24}$ As a result of this perspective it is not surprising that during this time, human rights activists, representatives of multilateral organizations, scholars, and diplomats increasingly have employed a legal framework-justice-to respond to gross human rights violators and war criminals. ${ }^{25}$ This paradigm of justice calls for perpetrators to answer for their crimes in a court of law. Precisely because wrongdoers, particularly the intellectual authors of the crimes, subvert the orderly functioning of civil society by instigating or unleashing mass horror, the use of law to restore appropriate social norms has assumed heightened importance. Consequently we aver that while transitional justice scholars recognize that many forms of reckoning are necessary, our reading of the human rights literature and international practice suggest that individual criminal trials-whether national, international, or a hybrid—have become the benchmark of accountability against which all other forms of reckoning, such as truth commissions, must be judged. ${ }^{26}$

24. The Western conception and development of human rights norms and protections, which is the dominant model, is rights-based and rooted in philosophical tradition of John Locke and the belief that individuals have moral rights to life, liberty, and autonomy. Therefore, it is not surprising that in the aftermath of the Second World War, human rights became the justification to establish an international framework of laws to enforce obligations by states to guarantee and protect individuals from the barbarities of state action. Thus, lawyers have assumed a prominent role in the development of the modern human rights movement. See Louis Henkin, Gerald L. Neuman, Diane F. Orentlicher \& David W. Leebron, Human Rights 73-91 (1999).

25. Neier, supra note 2; Post \& Hesse, supra note 3, at 19-20; The Report of the Century Foundation/Twentieth Century fund Task force on Apprehending Indicted War Criminals, Making Justice Work 5-6 (1998); Payam Akhavan, Justice in The Hague, Peace in the Former Yugoslavia? A Commentary on the United Nations War Crimes Tribunal, 20 Hum. Rts. Q. 739 (1998) [hereinafter Akhavan, Justice in The Hague]; RoHT-ArriazA, supra note 2; Cherif Bassiouni, Searching for Peace and Achieving Justice: The Need for Accountability 59 L. \& Contemp. Рrob. 1 (1996); Orentlicher, supra note 5.

26. See infra notes $2-25$, and accompanying text. Although there have been criticisms of the tribunals, these largely center on the extent to which the ad hoc tribunals have succeeded on their own terms and commentators have not advocated that justice be displaced by truth commissions or other models of accountability. See José E. Alvarez, Rush to Closure: Lessons of the Tadic Judgment, $96 \mathrm{MiCH}$. L. Rev. 2031, 2035 (1998); Tom J. Farer, Restraining the Barbarians: Can International Criminal Law Help?, 22 Hum. RTs. Q. 90 (2000). But see Mark A. Drumbl, Punishment, Postgenocide: From Guilt to Shame to Civis in Rwanda, 75 N.Y.U. L. Rev. 1221 (2000) (arguing for a context-specific approach to accountability for mass atrocity and postulating that the prevailing 
For many advocates, criminal trials offer the best opportunity simultaneously to achieve the essential attendant tasks of social repair. Many find support for this in the writings of legal scholars, notably Diane Orentlicher and Naomi Roht-Arriaza, who developed theoretical justifications for criminal trials in response to the transformation of countries emerging from dictatorships and civil wars, such as those in Latin America. ${ }^{27}$ Their immediate focus was on the duty of states under international law to prosecute perpetrators of gross human rights violations. When the conflict erupted in the Balkans, many of the same justifications for domestic prosecutions were raised to support the creation of an international criminal tribunal to prosecute Balkan war criminals, and later to put Rwandan genocidaires in the dock. ${ }^{28}$ The International Criminal Tribunal for the former Yugoslavia ("ICTY") was created in the midst of the war and one justification for its existence was the argument that war criminals must not evade accountability if there were to be peace in the region. ${ }^{29}$ The extent to which this was a motivating factor in the inception of the ICTY is unclear, given the need of the international community to take some action to

presumption in favor of individual trials may inhibit development of more appropriate mechanisms for social reconstruction).

27. Orentlicher, supra note 5; RoHT-ArRIAZA, supra note 5. During the 1980 s several countries were attempting democratization and the concerns of the human rights movement focused on the responsibility for successor states to the misdeeds of their predecessors. See generally, The Justice and Societr Program of The Aspen Institute, State Crimes: Punishment or Pardon (1989).

28. Theodor Meron, Answering for War Crimes: Lessons from the Balkans, 76 ForeIGN Aff. 2 (1997); José E. Alvarez, Crimes of States/Crimes of Hate: Lessons from Rwanda, 24 YAlE J. INT'L L. 365 (1999); see also Payam Akhavan, Justice and Reconciliation in the Great Lakes Region of Africa: The Contribution of the International Criminal Tribunal for Rwanda, 7 Duxe J. Comp. INT'L L. 325, 333-43 (1997); Akhavan, Justice in The Hague, supra note 25 .

29. There was widespread discussion of the "peace vs. justice" debate. In other words, the "realists" argued that the Bosnian Serb leadership, notably Radovan Karadšić, accused of war crimes, could not be threatened with prosecution because the international negotiators needed their cooperation with the peace process. The "moralists" argued that the leaders of the ethnic cleansing campaign must be held accountable to secure lasting stability in the country. See Akhavan, Justice in The Hague, supra note 25, at 734. In light of the ongoing war, domestic trials simply were not possible. Certainly, during the conflict the government of Bosnia-Herzegovina virtually had no opportunity to apprehend and prosecute suspected war criminals. The record of the few exceptions point to the vulnerabilities of a judicial system striving to operate in the midst of a war. In November 1992, two Bosnian Serbs, Sretko Damjanovic and Borislav Heric, were arrested and charged with war crimes by authorities in Sarajevo. The trials received much international attention and both defendants received the death penalty. Subsequently, these sentences have been reduced, in part because the Bosnian government revoked the death penalty to conform with required judicial restructuring brought about by the peace agreement. The trials also were subject to international criticism for lack of adequate due process, a claim that was strengthened when it came to light that two of the purported murder victims actually were alive and well in Sarajevo. 
address its reluctance to intervene militarily to stop the war. ${ }^{30}$ It is noteworthy that while the justifications for international criminal trials have gained momentum and added legitimacy with the drafting of the statute for the ICC, their purported efficacy largely has been imported uncritically from the experience of emerging democracies over the last twenty years. The result is that the theoretical foundation for international criminal trials borrows heavily from writings developed in a political and legal context in which such proceedings were mere aspirations and with no empirical data to substantiate the purported benefits of international trials. Consequently, advocates for trials may be overreading the implications of these earlier writings and applying a decontextualized framework. Further, little attention has been paid to the role of law in different cultures and how population expectations for justice may differ.

Though perhaps a consequence of the way in which legal scholars and activists promoted more generally the goal of anti-impunity for human rights violators, unfortunately, the emphasis on criminal trials overshadows attention to other options to achieve these same goals. In addition, the legal emphasis ignores the vast literature on collective violence. ${ }^{31}$ By choosing to focus so narrowly, many trial advocates justify their efforts under the assumption that a focus on legal processes is adequate to resolve the individual and social harm. We suggest that it is critical to acknowledge the contribution that individual trials can make while recognizing the limitations of the law to address the collective nature of the legacy of mass violence or gross human rights violations. While some scholars have suggested that these forms of legal redress have therapeutic results both for individuals and for societies, ${ }^{32}$ we will argue that the reasoning and evidence for such an assertion is flawed.

In this section, we examine the primary justifications in support of

30. Id. at 744. Gary Jonathan Bass expresses this critique of the ICTY even more forcefully, stating that "the establishment of the Hague tribunal was an act of tokenism by the world community, which was largely unwilling to intervene in ex-Yugoslavia but did not mind creating an institution that would give the appearance of moral concern." GARY Jonathan Bass, Stay the Hand of Vengeance: The Politics of War Crimes Tribunals 207 (2000). See also Teitel, Bringing the Messiah Through the Law, supra note 19, at 179.

31. See infra Conclusions, § $\vee$.

32. Martha Minow observes that therapeutic concerns have acquired prominence in discussions regarding accountability for mass atrocities that was not true at the time of the Nuremberg and Tokyo trials. MiNow, supra note 2, at 22; see also Neil J. Kritz, Coming to Terms with Atrocities: A Review of Accountability Mechanisms for Mass Violations of Human Rights, 59 L. \& Contemp. Probs. 127 (1996) (stating that in response to mass atrocities "groups and nations tend to function similarly to individuals."). Even those who note that the contribution of trials may be different for communities than for victims, accept the premise that prosecutions are critical for both. Julie Mertus, Only a War Crimes Tribunal: Triumph of the International Community, Pain of the Survivors, in War Crimes: The Legacy of Nuremberc 229, 232-37 (Belinda Cooper ed., 1999). 
criminal trials in order to highlight the links authors make between these proceedings and social repair. We then point out some theoretical limitations that underlie these assumptions and make reference to our recent study that offers empirical data that contradicts many of the traditional assumptions about the utility of criminal trials. A primary weakness of writings on transitional justice is the paucity of empirical evidence to substantiate claims about how well criminal trials achieve the goals ascribed to them. There have been few studies of the effects of criminal trials on victims, bystanders, and perpetrators, that is, how trials simultaneously are a response to societal atrocities and an intervention that may affect profoundly societal beliefs and attitudes. ${ }^{33}$ Similarly there have been virtually no studies that systematically have attempted to examine or measure the contribution of trials to reconciliation and social reconstruction.

In 1999, the Human Rights Center and International Human Rights Law Clinic at the University of California, Berkeley collaborated with the Centre for Human Rights at the University of Sarajevo in an interview study of Bosnian judges and prosecutors, entitled "Justice, Accountability and Social Reconstruction: An Interview Study of Bosnian Judges and Prosecutors" ("Study"). ${ }^{34}$ The Study employed qualitative methods to elucidate the perspective of Bosnian legal professionals on several topics, including their "perceptions of the relationship between criminal trials and social reconstruction." 35 The Study is part of a larger project undertaken to examine the views of multiple segments of Balkan society on the relationship between international criminal trials and social reconstruction. The Study does not purport to serve as a definitive evaluation of how well the ICTY is satisfying the goals transitional justice scholars have set for legal procedures. Nevertheless, it does provide some data on these critical issues and we draw on the Study to illuminate areas in which the predicted results of trials fall short. ${ }^{36}$ More study on this subject is needed and similar research should be

33. While not employing qualitative research methods, Mark Osiel has examined the impact of domestic and international trials on the formation of a collective memory about the past atrocities and the role of judges and prosecutors in constructing this public pedagogy criminal trials afford. Osiet, supra note 2.

34. Interview Study, supra note 20.

35. Id. at 103.

36. While this Study focused on a country-wide sample of thirty-two judges and prosecutors, additional support for the findings is found in companion studies involving houseto-house surveys, focus groups, and key informant interviews in the former Yugoslavia. Harvey Weinstein \& Eric Stover et al., Communities in Crisis: Justice, Accountability, and Social Reconstruction in Former Yugoslavia (June 2001) (on file with authors). This was one of a series of papers presented at the Sixth International Conference for Health and Human Rights, International Society for Health and Human Rights, Cavtat, Croatia, June 2001. The papers described preliminary results from surveys, focus groups, key informant interviews, and ICTY witnesses in ongoing studies of the process of social repair in Croatia and Bosnia-Herzegovina. Included in this symposium were papers by 
repeated, since opinions about the purpose and efficacy of the ICTY and criminal trials may change over time.

In general, advocates of international criminal trials for perpetrators of mass violence believe that trials will help communities rebuild because trials support one, if not all of the following goals: (1) to discover and publicize the truth of past atrocities; (2) to punish perpetrators; (3) to respond to the needs of victims; (4) to promote the rule of law in emerging democracies; and (5) to promote reconciliation. We address each goal in turn.

\section{Discovering and Publicizing the Truth}

Transitional justice scholars largely agree that a necessary foundation for healing a society that has experienced mass violence is learning the truth about what happened. The transparent rendering of the once secret or officially denied events by governments or aggressing parties through a judicial process is believed to have several curative properties. These salutary effects include countering and condemning prior denials or partial disclosures of abuses ${ }^{37}$ and creating a new, authoritative, and impartial record about the past that can serve as a basis for a new national consensus. ${ }^{38}$

The importance of state-sponsored truth-seeking mechanisms is based upon an assumption made by some scholars that the ongoing suffering of

Miklos Biro et al., A Survey of Attitudes Towards Social Reconstruction in Vukovar and Mostar; Dean Ajdukovic and Dinka Corkalo, Barriers and Facilitators to Social Reconstruction in Vukovar, Croatia; and Dino Djipa and Mirsada Muzur, A Study of Attitudes to Justice and Reconciliation in Mostar. These data suggest that although most people will indicate their support for trials of all war criminals, they do not acknowledge specific alleged atrocities committed by members of their own national group. Further, the relationship of criminal trials to reconciliation is not apparent to many of the respondents.

37. Minow, supra note 2 , at 50; IgnatiefF, supra note 2, at 183 . During periods of mass violence, the state often denies that it is responsible for abuses and may employ tactics like disappearances and torture that are designed to obscure the nature of the state's involvement. Nunca Más, supra note 9, at 3. For example, the disappearances and torture in Latin America in the 1980s galvanized activists to support the need to hold criminal trials of past wrongdoers. Thus, efforts to put in the dock military officials responsible for state-sponsored death squads, executions, and torture of civilians are lauded as a way for the truth to come out about the government's deliberate policy of repression.

38. Michel Feher argues that indeed, one of the tasks of the ICTY is not only to prosecute particular crimes, but through the trials to repudiate and stigmatize the political project of the Bosnian Serb regime. Michel Feher, Terms of Reconciliation, in Human RIGHIS IN Political Transitions, supra note 2, at 337; Neier, supra note 4, at 39; Teitel, Bringing the Messiah Through the Law, supra note 19, at 181; Minow, supra note 2, at 123; M. Cherif Bassiouni, Searching for Peace and Achieving Justice, 50 L. \& Contemp. Probs. 9, 24 (1996). 
individual victims and their families is caused by not knowing the facts that led to their loss or not having official acknowledgment of their suffering. Further, the acquisition of knowledge and publication of the facts by the state liberates these victims from being trapped in the past, unable to rebuild their lives. ${ }^{39}$ Moreover, transitional justice scholars assume that the effects on society of discovering the truth are comparable to the effects on individuals. ${ }^{40}$ Just as individuals become mired in past traumatic events, so too do societies. Thus, in the conventional vocabulary, trials are a critical mechanism to discover and convey the truth about the horrors of the past and set societies free.

We suggest that advocates for criminal trials have been influenced by and find support for their views in the early writing of transitional justice scholars. For example, international law expert, Diane Orentlicher elevates the impact of judicial truth-making by arguing that "the most authoritative rendering of the truth is possible only as a result of judicial inquiry, and major prosecutions can generate a comprehensive record of past violations." ${ }^{41}$ The trial record as a public document as well as its contents--a detailed description of the crimes-counters the silence or denial of the past period. Currently, this conception is shared by commentators and practitioners who believe that due to a widespread acceptance of the impartiality of multilateral institutions, international criminal trials confer heightened legitimacy to the truth as captured in the judicial record. ${ }^{42}$

What are the limitations of this assumption? Much of the literature holds

39. Assisting victims to "move beyond" their injury frequently is tied to the utility of trials in assisting in successful transitions since if victims do not perceive justice to be done, they may resort to violence to settle their scores. Kritz, supra note 32 , at 128 . The first President of ICTY, Antonio Cassese has echoed this call, stating that the Tribunal could squelch the desire for revenge among victims by rendering justice to them to avoid "feelings of hatred and resentment seething below the surface [to] ... erupt and lead to renewed violence." International Tribunal for the Former Yugoslavia: First Annual Report, at 10, U.N. Doc. IT/68 (28 July 1994) quoted in Akhavan, Justice in The Hague, supra note 25, at 766. See also Mertus, supra note 32, at 233.

40. Kritz, supra note 32, at 127; Jon M. Van Dyke, The Fundamental Human Right to Prosecution and Compensation, 29 DEN. J. INT'| L. \& PoL'Y 77 (2001); see also Minow, supra note 2, at 123.

41. Orentlicher, supra note 5 , at n.32. Over the last decade transitional justice scholars have examined the process and outcomes of multiple truth commissions. This experience suggests that, depending upon the context, other truth-telling mechanisms play an important role in documenting and disseminating historical events.

42. Similarly, commentators ascribe to the ICTY the task of establishing a record of what happened during the conflict, of "who did what to whom" such that Bosnians will have an accurate accounting of the conflict that can serve as the basis to debate, discuss, and bring about national reconciliation. Teitel, Bringing the Messiah Through the Law, supra note 19, at 181 ("It has almost become dogma in contemporary foreign policy that establishing the 'truth' about a state's repressive past can lay the foundation for national reconciliation."); Akhavan, Justice in The Hague, supra note 25, at 774. 
that trials create an authoritative record capable of withstanding historical revisionism. ${ }^{43}$ As the public apprehends the true "facts," denial of the events becomes impossible. Public debate must now consider criminal activities that were perpetrated in the name of the state. ${ }^{44}$ This thesis assumes that the judicial record will outweigh individual and group rationalizations for an alternative interpretation of the past. Further, it assumes that everyone will accept the facts as stated and that they will not distort the record based upon philosophical, moral, or political allegiances. There is no reason to make the assumption in the context of accountability for mass violence that the "truth" will produce the intended epiphany. The theory implies that trials will facilitate approbation of the perpetrators and rejection of the political agenda that produced the criminal acts. ${ }^{45}$ Yet, the truth is constituted by multiple facts, each of which is vulnerable to distortion, denial, rationalization, and refutation.

For example, Study participants were asked whether they believed that genocide occurred in Bosnia-Herzegovina during the conflict and, if so, against whom. ${ }^{46}$ The subject of genocide, with its emotional overtones of mass suffering, increased legal sanction ${ }^{47}$ and moral approbation, serves as an indicator of how participants characterized the violence of the conflict, i.e., their understanding of the "truth" that needed telling.

Responses to questions about genocide were remarkably similar between members of the same national group. In general, Bosniak ${ }^{48}$ legal

43. Neier captures many of these perspectives in his observation about the functions of truth telling that trials embody, such as the fulfillment of an "obligation to the victims, their families, and friends . . . a means to resolve any doubts about what happened . . . a way to establish a record that, in and of itself, is an expression of respect for the worth of the victim . . . a means to stigmatize those who committed great crimes; and . . . a way to resist predictable attempts to rewrite history." Neier, supra note 4, at 39.

44. Akhavan, Justice in The Hague, supra note 25, at 774-81. Akhavan argues that through selective prosecution of the political and military leaders in the former Yugoslavia, the ICTY can maximize its truth telling impact by depicting the overall pattern and effect of the campaign of ethnic cleansing. Some scholars have noted that the ability of trials to inculcate acceptance of the truth will be tempered by access to information and the local political climate. Minow, supra note 2, at 123-26.

45. Feher, supra note 38 , at 336-37.

46. See Interview Study, supra note 20, at 163 (Appendix E). Specifically, participants were asked: "In your legal opinion, did genocide happen anywhere in Bosnia-Herzegovina? To whom/Against whom?" Id.

47. Customary international law establishes that states have an obligation to prosecute the crime of genocide and states may exercise universal jurisdiction over defendants to do so. See Orentlicher, supra note 5, at 2565.

48. The three largest national groups in Bosnia are Bosnian Croats (Roman Catholic), Bosnian Serbs (Orthodox), and Bosnian Muslims. In the course of the 1992-1995 conflict in Bosnia-Herzegovina, the Bosnian Muslim community self-identified their national origin as "Bosniak," to emphasize the cultural and de-emphasize the religious character of their community. 
professionals were unequivocal and consistent in their statements that genocide against Bosniaks occurred during the war, while Bosnian Serb participants tended to state that genocide occurred against all three sides, that they had no knowledge of any acts of genocide or that genocide did not occur at all. Bosnian Croat legal professionals were willing to state that genocide occurred, but if so, that all three sides had suffered it. ${ }^{49}$ In addition, those who lived in areas where large-scale atrocities took place were specific about the need for those crimes to be prosecuted..$^{50}$

Rather than a consensus that the ICTY trials had instructed them about past atrocities, the responses of legal professionals suggest that trials are viewed primarily to confer legitimacy on the status of the respondent's national group as victims rather than to investigate atrocities committed by all forces or to learn what crimes, if any, were committed in the name of the respondent's national group. The Study found that all participants sought to represent themselves as members of a national group that was the target of aggression in the conflict. ${ }^{51}$ None advanced the view that trials were necessary to learn what crimes "their" forces had committed..$^{52}$ The Study indicated that legal professionals assumed they knew the essential "truth" about what happened during the war and which forces were responsible for major atrocities. The truth is something that trials can acknowledge, but not something that legal processes are needed to discover. Thus we suggest that international criminal trials, by themselves, are not able to inculcate citizens with a particular understanding of the past.

\section{Punishing Perpetrators}

Trials are a state-sponsored mechanism to hold perpetrators accountable for their acts. Based upon various theories of punishment, accused perpetrators stand trial, face their accusers, and if convicted, are punished and stigmatized for their past actions. ${ }^{53}$ Incorporating utilitarian and retributivist theories of justice, the suffering of victims may be acknowledged as well as the responsibility of the accused for the harm caused. ${ }^{54}$ Advocates of

49. Interview Study, supra note 20, at 147-48. For a comparison of responses, see id., App E.

50. Id. at 135 .

51. Id. at 147 .

52. Id.

53. Naomi Roht-Arriaza, Punishment, Redress, and Pardon: Theoretical and Psychological Approaches, in Impunity and Human Rights: International law Practice, supra note 2, at 1317. See Jaime Malmud-Goti, Transitional Governments in the Breach: Why Punish State Criminals?, 12 Hum. RTs. Q. 1, 11-13 (1990).

54. See Roht-Arriaza, supra note 53, at 16. Roht-Arriaza observes that the additional approaches to punishment-a denunciation model and "goal-oriented retributivism" form the basis of a victim-centered model of punishment for gross human rights abuses 
criminal trials frequently assert that retributive justice serves the needs of victims. ${ }^{55}$ Accountability provides a direct, moral, and ethical response to victims on behalf of society that demonstrates that the state is validating their innocence and their lack of culpability in the deeds. The pain and experiences of victims are acknowledged and compensated by punishing perpetrators for their crimes. Various transitional justice scholars imply that retribution makes a unique contribution to the alleviation of the pain victims experience. ${ }^{56}$

In addition, the prevailing belief among scholars and activists is that punishment of the perpetrators serves the societal goals of re-enforcing acceptable norms, removing potential threats to a new regime and deterring future abuses. As scholar Martha Minow notes about the power of trials: "guilty verdicts afford public acknowledgment of what happened, and its utter wrongfulness. ${ }^{57}$ Particularly for successor regimes, sanction of war criminals communicates publicly that the past horrors deserve societal condemnation. ${ }^{58}$ When an international tribunal delivers judgment, the

that has informed much of the thinking about and activism on behalf of those who have been targets of repression and violence. As Martha Minow stated, retribution can be understood as vengeance curbed by the intervention of someone other than the victim and by principles of proportionality and individual rights. Retribution motivates punishment out of fairness to those who have been wronged and reflects a belief that wrongdoers deserve blame and punishment in direct proportion to the harm inflicted. Otherwise, wrongdoers not only inflict pain but also degrade and diminish victims without a corrective response. Minow, supra note 2, at 12; see also Orentlicher, supra note 5, at 1550-51. But see Malmud-Goti, supra note 53, at 14-15 (rejecting retributivism as basis for prosecutions and instead arguing that restoration of the dignity of a society and reformation of the institutions responsible for terror should inform state policy regarding prosecutions and thus individual trials are not mandated for all perpetrators).

55. Neier, supra note 4 , at 49 (trials may constitute an "acknowledgment by the world at large ... of the suffering inflicted on the victims: and prosecutions have the capacity to speak on behalf of the victims"); Mertus, supra note 32, at 235 (war crimes trials assist victims because "the individualization of guilt meets their desire for revenge"). See also Bassiouni, supra note 38, at 26; Kritz, supra note 32, at 128; Roht-Arriaza, supra note 53 , at $19-20$.

56. See infra note 55 .

57. Minow, supra note 2 , at 123.

58. Jaime Malmud-Goti, an advisor to Argentine President Alfonsin, states that criminal trials enable the state to express "institutional disapproval of official policies that resulted in the violation of human rights" during the prior regime. Jaime Malmud-Goti, Trying Violators of Human Rights: The Dilemma of Democratic Governments, in THE Justice and Society Procram of The Aspen Institute, State Crimes: Punishment or Pardon 71, 81 85 (1989). Orentlicher argues that customary international law obligates states not to condone wholesale impunity of past crimes. Orentlicher, supra note 5, at 2599 . And Teitel observes that " $[\mathrm{t}$ rials offer a transitional mechanism for normative transformation to express public condemnation of aspects of the past." Ruti Teitel, Transitional Jurisprudence: The Role of Law in Political Transformation, 106 YALE L.J. 2009, 2037 (1997). See also Kritz, supra note 32, at 128. 
ability of the law to express these values is amplified to embody universal norms. ${ }^{59}$

Deterrence remains an oft-cited justification for international criminal trials. Advocates of trials contend that accountability is necessary to prevent future violations. ${ }^{60}$ In addition, proponents suggest that political and military leaders will moderate their policies and actions to comply with international standards if they believe that they will be held accountable for egregious violations. ${ }^{61}$ However, some are outright skeptical about whether trials can have any preventative value whatsoever. ${ }^{62}$

59. Diane Marie Amann, Assessing International Criminal Adjudication of Human Rights Atrocities, THIRD WORLD L. STUD. (forthcoming 2001); Neier, supra note 4 , at 49 (international prosecutions convey world-wide condemnation of the crimes committed and those who carried them out). See also Kritz, supra note 32, at 129 (international tribunals are superior to domestic proceedings because the former are "better positioned to convey a clear message that the international community will not tolerate such atrocities").

60. Akhavan, Justice in The Hague, supra note 25, at 743-51; Malmud-Goti, supra note 58 , at 81-82; Bassiouni, supra note 38, at 18-19; Kritz, supra note 32, at 128; Orentlicher, supra note 5, at 2542. See also Meron, supra note 28, at 6-8 (although the ICTY did not prevent the commission of massacres in Bosnia, the prosecution of war criminals serves to underscore the commitment of the international community to achieve accountability for these crimes).

61. Generally, proponents of criminal trials frame the links between deterrence and impunity, in the negative, i.e. the failure to punish leaders for past atrocities serves to signal to future despots that they too will enjoy impunity. For example, Hitler's remark to his military leaders-"Who after all is today speaking about the destruction of the Armenians"-regarding the lack of Turkish accountability for the genocide of Armenians is cited to highlight the risks of a climate of impunity. Hitler's speech to chief commanders and commanding generals, 22 Aug. 1939, quoted in The Century Foundation/Twentieth Century Fund Task Force on Apprehiending Indicted War Criminals, MAKING JUSTICE WORK 29 (1998). A legal advisor for the ICTY prosecutor offers a slightly more optimistic account of the possibilities of deterrence. While observing that the threat of criminal sanction did not prevent the massacre at Srebrenica, Bosnia, Payam Akhavan notes that in the midst of the Bosnian conflict, the international condemnation of Bosnian Serb concentration camps in the Prijedor region of Bosnia caused Bosnian Serb military and political leaders to close the camps and saved thousands of lives, suggesting that international pressure can have the effect of specific deterrence. Akhavan, Justice in The Hague, supra note 25, at 751. This suggests the power of international journalistic exposure of atrocities to affect the actions of perpetrators.

62. Carlos Nino, Radical Evil on Trial x (1996). Carlos Nino is markedly cautious regarding ability of retributive justice to deter perpetrators of what, borrowing from the philosopher Emmanuel Kant, he terms "radical evil." Nino postulates that regimes that unleash mass terror can only exist under a narrow set of political circumstances-primarily where totalitarian or authoritarian governments take hold. Thus it is "not clear whether punishing radical evil can prevent similar evil acts from taking place when these favorable conditions are present, nor is it clear whether punishment forestalls the emergence of these conditions." $I d$. Bass argues that trials are, at best, of limited deterrence value and notes that there would need to be a credible threat of trials in order to change the expectations of architects of mass violence that they likely will evade justice. BAss, supra note 30 , at 290-95. See also Roht-Arriaza, supra note 53 , at 14-15 (for a deterrent threat to be credible, it must come from outside the country in which the violations occurred). 
The principal limitation of this perspective is that there are no empirical data to suggest that trials deter war crimes or gross human rights violations. In addition, the focus on punishment of perpetrators may have the inadvertent consequence of transforming these wrongdoers into scapegoats or victims in order to perpetuate the political mythology of a particular social group. This may exert an untoward effect that undercuts the advantages of punishing perpetrators. ${ }^{63}$

While all participants subscribed to the consensus view that those guilty of war crimes should be held accountable ${ }^{64}$ and cited deterrence as one of the purposes of criminal law, ${ }^{65}$ only the views of the Bosniak participants conformed to the generally-stated retributive goals for trials advocated by most transitional justice experts. The call for punishment of named perpetrators was loudest and most precise among Bosniak participants. ${ }^{66}$ Bosnian Serb and Bosnian Croat participants-members of groups the international community has condemned as perpetrators of war crimes-called for accountability in general terms or placed such claims in the context of the need for international accountability to recognize the experiences of their national group as victims of war atrocities. We believe that trials may not overcome feelings of victimization and loss of control created by the conflict. Individuals, particularly bystanders of a group that committed war crimes, may not be ready to accept the stigmatization that trials are intended to confer. ${ }^{67}$

\section{Responding to the Needs of Victims}

Supporters of a legal response to war crimes and gross human right violations almost ritualistically justify international criminal trials as necessary to meet the needs of victims for the truth, acknowledgment of suffering,

63. Scholars criticize criminal trials for selective prosecutions and/or retroactive application of legal norms. See, e.g., Minow, supra note 2, at 30-47; Teitel, Bringing the Messiah Through the Law, supra note 19, at 187-88. However, we suspect that the curative effect of trials on victims and communities is less than expected and thus we argue that attention should be paid to developing other mechanisms to achieve these same goals.

64. See Interview Study, supra note 20 , at 151.

65. Id. at 115 .

66. Id. at 147.

67. This is particularly problematic since many bystanders likely could have acted to save victimized individuals. See David H. Jones, Moral Responsibuity in the Holocaust: A Study in the Ethics of Character 216 (1999) (concluding that many bystanders in Europe during World War II had the opportunity to assist jews at little personal risk and thus are blameworthy for their inaction). Therefore the normative approbation of international criminal trials should be absorbed by this group of bystanders if accountability is to achieve its aspiration of deterrence. 
justice, and healing. ${ }^{68}$ Many transitional justice scholars find support for criminal trials in the literature on treatment of trauma survivors as well as anecdotal evidence. ${ }^{69}$ The trauma literature cited suggests that victims who are able to recount the events of their victimization in the context of acknowledgment and support may be able to receive the benefits of closure. $^{70}$ By analogy, some legal scholars cite this to support their arguments that criminal trials that elucidate the facts will serve the same healing function for survivors. ${ }^{71}$ This catharsis comes in the context of public acknowledgment that links suffering of survivors to the stigmatization of the perpetrators and further removes public claims or private suspicions that the victims were in any way responsible for their fates. Thus the actions of the state or international community can restore dignity to those wrongfully injured and help to heal their wounds.

The principal limitation of this view lies in the hypothesized "therapeutic" nature of criminal trials for victims of mass violence. This hypothesis is based upon a profoundly simplistic view of how psychotherapy works. It long has been known in the psychological literature that while catharsis may have short-term benefit for some, healing is a long-term process that

68. Frequently, advocates for criminal trials argue that the needs of victims will be addressed by accountability and thus transform private thirst for vengeance into public procedures of legal accountability. See infra note $\mathbf{8 7}$ and accompanying text. However, other scholars emphasize the need for trials explicitly to acknowledge and honor the injuries of victims. Professor Catharine A. MacKinnon, Address at Amnesty International, U.S.A., Legal Support Network Annual Meeting (17 Sept. 2000); Mertus, supra note 32; see also Kritz, supra note 32, at 128; Bassiouni, supra note 38, at 23-24. Some of these needs, like the need to know what happened to family members, public acknowledgment of the harms they endured, and condemnation of the perpetrators overlap with some of the other societal aspirations for international criminal trials, yet assume a distinct character in regard to individual victims.

69. Roht-Arriaza, supra note 53, at 19-21. Commentators draw upon the writings of Judith Herman, a psychiatrist who has worked with victims of trauma and torture to substantiate the link between public testimony and individual healing. JUDITH LEWIS Herman, Trauma and Recovery 133, 155, 183 (1992). See Ilene Cohn, The Protection of Children in Peacemaking and Peacekeeping Processes, 12 HARv. Hum. RTs. ). 129, 179; Jamie L. Wacks, A Proposal for Community-Based Racial Reconciliation in the United States Through Personal Stories, 7 VA. J. Soc. PoL'y \& L. 195, 205-07 (2000).

70. Roht-Arriaza, supra note 53, at 21; see David A. Crocker, Reckoning with Past Wrongs: a Normative Framework, 13 EthICS \& INT'L AfF. 43, 52 (1999) (transitional governments should enable public testimony by victims to receive respect and sympathy which will enable empowerment of victims); Minow, supra note 2, at 66-74 (the author accepts that victims may be assisted through the opportunity to testify about their experience, but favors truth commissions over trials as a more therapeutically appropriate forum for this purpose).

71. Minow, supra note 2, at 88-89; see also Mackinnon, supra note 68; Mertus, supra note 32 , at 232-34 (noting the salutary effects of testimony may not be shared by all victims and that not all dimensions of injury will be aired in court). 
involves significantly more than emotional abreaction. ${ }^{72}$ For some, the performative aspects of courtroom testimony may not be therapeutically in their best interests. ${ }^{73}$ For others, individual criminal accountability may not be most significant for healing. ${ }^{74}$ Complicating this perspective is the

72. Psychiatrist Judith Herman in her book, Trauma and Recovery, notes as well:

Patients at times insist upon plunging into graphic, detailed descriptions of their traumatic experiences, in the belief that simply pouring out the story will solve all their problems. At the root of this belief is the fantasy of a violent, cathartic cure which will get rid of the trauma once and for all ... [this] is fueled by images of early, cathartic treatments of traumatic syndromes which by now pervade popular culture, as well as by the much older religious metaphor of exorcism.

HERMAN, supra note 69 , at 172 . The classical literature of psychotherapy practice suggests that it may be helpful for someone attempting to deal with untoward events in her life to unburden herself in the context of a trusted listener. See C. Peter Rosenbaum \& John E. Beebe, Psychiatric Treatment: Crisis, Clinic, Consultation 259 (1975). However, Rosenbaum and Beebe note the danger of "injudicious catharsis" where opening up these memories and associated feelings may have negative effects. Further, they caution against premature catharsis and indicate that the context must be established where overwhelming memories can be contained and explored over time. Anne Bernstein and Gloria Marmar Warner, in An Introduction to Contemporary Psychoanalysis, describe how Freud reported that verbalization in a non-judgmental environment could produce a catharsis that led to relief of symptoms. Anne Bernstein \& Gloria Marmar Warner, An Introduction to Contemporary Psychoanalysis (1981). However, the clear importance of a supportive trusting relationship and the development of insight over time is emphasized. For more recent work that grows out of evidence-based studies, see Edna B. Foa \& E.A. Meadows, $P_{\text {sychosocial Treatments for Post-traumatic Stress Disorder: a Critical }}$ Review, 48 Ann. R. Psychol. 449-80 (1997); Edna B. Foa, Psychosocial Treatment of Post-traumatic Stress Disorder, 61 J. Cun. Psychiatry (Suppl. 5), 43-47 (2000); The Expert Consensus Guideline Series, Treatment of Posttraumatic Stress Disorder, 60 J. CuN. Psychiatry (Suppl. 16) (Edna B. Foa et al. eds. for series, 1999). These papers suggest that, while experimental studies indicate that a variety of modalities of treatment such as exposure therapy, cognitive therapy, stress inoculation training, and medication may be useful, long-term studies and further research are essential. Foa notes, in her article on psychosocial treatment of post-traumatic stress disorder (PTSD) that "for treatment to be maximally beneficial, therapists should promote patients' trust and cooperation." Foa, Psychosocial Treatment of Post-traumatic Stress Disorder, supra at 47. See Wendy Orr, Reparation Delayed is Healing Retarded, in Looking Back Reaching Forward: Reflections on the Truth and Reconciliation Commission of South Africa 239, 240 (2000) (the author argues healing must be understood as a process rather than as an event and that many factors contribute to this process such as reparations and public acknowledgment); see also Derek Summerfield, Addressing Human Response to War and Atrocity: Major Challenges in Research and Practices and the Limitations of Western Psychiatric Models, in Beyond Trauma: Cultural and Societal Drnamics 17, 22-24 (Rolf J. Kleber et al. eds., 1995). In sum, our reading of the literature suggests that "healing" is a long-term process that requires far more than testimony in a courtroom or truth commission setting.

73. Nomfundo Walaza, South African psychologist and Director of the Center for Survivors of Violence and Torture, has worked with victims who testified before the South African Truth and Reconciliation Commission ("TRC"). She has observed that "revealing is not healing" and that many witnesses did not experience "closure" as a result of their appearance before the TRC. Nomfundo Walaza, Trauma Counseling in the South African Context (Nov. 2001) (available from Walaza at Center for Survivors of Violence and Torture, Cape Town, South Africa).

74. In the interviews with over ninety-five key informants in Croatia and Bosnia the question of forgetting versus remembering is open to ongoing debate. While virtually all 
influence of culture in determining beliefs about the causes and meaning of catastrophic events, which in turn establishes the framework for individual and collective interpretations of the past. ${ }^{75}$ One shortcoming with the approach of traditional legal theorists is that they do not take into account other cultural modes of interpreting the aftermath of untoward events and their consequences. More study is needed to understand the meaning of legal actions, like trials, in particular cultural contexts.

\section{Promoting the Rule of Law}

Another justification for criminal prosecutions of perpetrators of mass atrocities is that trials serve as powerful symbols of a new government's intent to "break with the past." ${ }^{\text {" }}$ Particularly when trials are initiated by domestic regimes emerging from a violent period, transitional justice authors suggest that the government's willingness to hold wrongdoers accountable signals to citizens that the repression has ended and the country is entering a new period of reform. ${ }^{77}$ However, cooperation with international trials also signals a desire on the part of the new regime to

respondents accept the premise that war criminals should be prosecuted, many express concern that trials open old wounds and do not lead to social repair. Further, for many economic revitalization and jobs would be more salient contributions toward their "healing." See also Interview Study, supra note 20, at 150.

75. Summerfield, supra note 72, at 24-25; Arthur Kleinman, Writing at the Margin: Discourse Between Anthropology and Medicine 173-89 (1995); Laurence J. Kirmayer, Cultural Variations in the Response to Psychiatric Disorders and Emotional Distress, 29 Soc. ScI. MED. 327 (1989).

76. Malmud-Goti, supra note 58, at 51-58 (arguing that criminal trials of military officers responsible for gross human rights abuses conveys to the public governmental disapproval of prior practices and underlines the discontinuity between the previous regime and the transitional government); OsIEL, supra note 2, at 28-29 (criminal trials by transitional regimes can consolidate public consensus and public rejection of the violence perpetrated and affirm shared values of respect for human rights); Hesse \& Post, supra note 3 , at 15 (the authors observe that "successful transitions require new democratic regimes to distinguish themselves from the practices and culture of their predecessors" and conclude that the consensus among scholars is that past crimes should be prosecuted, "if at all feasible"); Orentlicher, supra note 2, at 2543 ("By demonstrating that no sector is above the law, prosecutions of state crimes can foster respect for democratic institutions and thereby deepen a society's democratic culture.").

77. See Orentlicher, supra note 2; Kritz, supra note 32, at 132-33; Akhavan, Justice in The Hague, supra note 25 , at 749 (international tribunals by stigmatizing behavior can change culture and thus contribute to "habitual lawfulness" within countries); Rutı G. Tettel, Transitional Justice 28-30, 66-67 (2000) (criminal trials in transitional periods promote rule of law not simply by enforcing existing norms, but critically by instantiating a normative shift in society to reject the persecutory policies of the prior regime); cf. Feher, supra note 38 , at 330 (the author emphasized that the goal of transitional regimes is to "repudiate the agenda of the former rulers" that trials will not necessarily guarantee this result and more germane are political debates about the nature of the transitional process itself). 
confront the past. Trials are effective symbols because a legitimate judicial process is the antithesis of violence. Through the judicial process, a new regime is understood to re-establish the orderly function of the civil state and so triumph over those who had deployed state power violently to achieve their own ends, bringing about the destruction of civilians and subverting state institutions.

Indeed, the symbolism of trials goes beyond demarcating the boundary between a violent past and peaceful future. Trials also represent a substantive claim about the legal character of a new regime. Legitimate trials require a functioning judicial system and so their relative success indicates the degree to which the rule of law has taken hold. ${ }^{78}$ However, in the case of international trials, the ability of international proceedings to support the efficient and impartial administration of justice on home soil, is far more attenuated. ${ }^{79}$

78. For example, some scholars have suggested that the overriding goal of the international community's involvement in Bosnia and Herzegovina should be to establish and promote the rule of law and, while desirable, war crimes prosecutions are a byproduct of these efforts rather than an ultimate objective. Indeed, the United Nations Security Council stated this aspiration explicitly by establishing the Tribunal under the United Nations' Chapter 7 powers (i.e., the tribunal was justified on the basis that it was needed to restore peace in the region). ICTY Statute, supra note 13. Thus the ICTY embodied the hope that the rule of law could restore peace (where UN troops had failed). See Teitel, Bringing the Messiah Through the Law, supra note 19, at 179. International prosecutions by themselves cannot "substitute for the establishment of the rule of law within domestic legal systems." Hesse \& Post, supra note 3, at 19. Thus many see the goal of the ICTY as encouraging Bosnian officials to create a judicial system capable of trying the hundreds, if not thousands of perpetrators of war crimes. Id. The success of this effort depends, according to Teitel, on how the legal culture of the local judiciary engages in social transformation. Ruti Teitel, Transitional Jurisprudence: The Role of Law in Political Transformation, 106 Y ALE L. J. 2009, 2026, 2030-31 (1997). This has led some to argue that efforts at enforcing international law should be subordinate to promoting the rule of law itself. Hesse \& Post, supra note 3, at 19 . Nino also concludes that the need to promote democracy should be paramount to the duty to punish and that rather than a retrospective approach, nations should have a duty to safeguard human rights and prevent violations. Under this approach, if a country were not able to prosecute past violators because prosecutions would threaten democracy, the international community would take responsibility to uphold the general duty to safeguard human rights. NinO, supra note 62, at 188 .

79. Teitel, Bringing the Messiah Through the Law, supra note 19, at 189 (noting that the location of the ICTY outside the region makes it difficult for the tribunal "to relate its trials and indictments to the actual conflict on the ground"). However, Payam Akhavan writing more recently, argues that the records of the ICTY and the ICTR support the contention that international criminal tribunals have strengthened democracies in Rwanda and the Balkans by removing (through detention and trial) or discrediting the political leaders responsible for or supportive of the atrocities in those countries. Payam Akhavan, Beyond Impunity: Can International Criminal Justice Prevent Future Atrocities?, 95 AM. J. INT'L L. 7, 8-9 (2001). Nevertheless, the question remains how we measure "the strengthening" of democracies, and even more critically, cause and effect. 
For example, in Bosnia, the equivocal nature of the peace meant that the postwar government was dominated by the same political parties as controlled the combatants during the conflict. As captured by the words of one participant: "Who ordered this war? Who is accountable for it? It was politicians." 80 Across the three major national groups in the Study, legal professionals adamantly condemned the role of politicians and politics in the post-war period. ${ }^{81}$ From their perspective, there has been no symbolic break with the past. In their view, politicians are corrupt, caused the war, and are responsible for inscribing national group identity in the political system. ${ }^{82}$

Additionally, while all respondents saw as critical the need for the rule of law in Bosnia and Herzegovina, none explicitly connected ICTY trials with the establishment of the rule of law domestically. ${ }^{83}$ Far more significant to legal professionals was the goal of political, legal, and economic integration with Western Europe. ${ }^{84}$

The significant limitations of justifying trials as symbols are that the focus on legal processes may divert attention from the multiplicity of symbolic efforts helpful to establish the credibility of a new regime. Further, as Mark Osiel has noted, burdening transitional justice trials with symbolic meaning may interfere with the ability of judges, lawyers, and juries to produce legitimate verdicts. ${ }^{85}$

\section{Promoting Reconciliation}

The transitional justice literature is replete with discussion of the need for societies to "heal" after mass violence. Writers frequently employ a biomedical model of trauma treatment to conceptualize the tasks of social recovery for a country that experienced mass violence. Trials are promoted

80. Interview Study, supra note 20 , at 119 .

81. Id. at $119-20$.

82. Id. at 119. In the immediate post-war period in Bosnia and Herzegovina, political parties were formed and organized according national groups, e.g., a Bosnian Croat party, a Bosniak party, and a Bosnian Serb party. More recently, newer political parties have formed that have incorporated members from each national group.

83. In particular, many Bosniak and Bosnian Croat legal professionals expressed the opinion that the ICTY was necessary to assure prosecution of war criminals, particularly prominent ones. At the same time, legal professionals also stated that the lack of clarity about ICTY procedures and in particular the interface between the ICTY and domestic war crimes prosecutions left them with the impression that the ICTY was hindering, rather than enabling domestic prosecutions of suspected war criminals. Id. at 145.

84. Id. at 116 .

85. Osift, supra note 2 , at $59-78$ (the dilemma of trials of perpetrators of "administrative massacres" is that the dramatic imperatives of legal storytelling may interfere with the due process rights of defendants). 
as a way for societies to engage in a painful but necessary discussion about the past in order to "come to terms" with the recent horrific events, to achieve "closure," and to rebuild a "healthy society" free of the encumbrances that destroyed its civic stability. ${ }^{86}$

Further, trials are justified on the grounds that individual criminal accountability promotes reconciliation. Criminal prosecutions serve to highlight the moral claim that individuals and not groups are responsible for acts of violence. The stated claim is that holding individuals accountable for these acts alleviates collective guilt by differentiating between the perpetrators and innocent bystanders, thus promoting reconciliation. ${ }^{87}$ In the

86. One expression of this perspective on the priorities for national recovery (though not specific to criminal trials) is captured by Tina Rosenberg in her book about social transformation in Eastern Europe:

Nations, like individuals, need to face up to and understand traumatic past events before they can put them aside and move on to normal life. This is important for the victims, who can truly heal and resume their contributions to society only when their dignity and suffering have been officially acknowledged. But it is just as important for the collaborators. Preventing dictatorship's return requires a full understanding of the mechanisms of dictatorship.

ROSENBERC, supra note 2, at xviii. Mark Osiel offers a variant on this theme, emphasizing that the performative aspects of criminal trials can assist "[a] traumatized society that is deeply divided about its recent past ... [through] collective representations of that past, created and cultivated by a process of prosecution and judgment, accompanied by public discussion about the trial and its results." OsIEL, supra note 2, at 39; see also Kritz, supra note 32, at 127 ("Societies shattered by the perpetration of atrocities need to adapt or design mechanisms to confront their demons, to reckon with these past abuses. Otherwise, for nations, as well as for individuals, the past will haunt and infect the present and future in unpredictable ways."); but see lonatiefF, supra note 2 at 184 (noting that trials may not lead to reconciliation since "the community from which the perpetrators come may feel that they have been made scapegoats" and thus resist the pedagogic aspect of public trials).

87. As Karl jaspers wrote regarding the Nuremberg trials: "For us Germans, the advantages . . . are its distinction between the definite crimes of the leaders and its very failure to condemn the people as a whole." JASPERS, supra note 1, at 58. Similarly, judges at the ICTY and several contemporary commentators subscribe to the idea that one of the most significant contributions of international tribunals is to create an historical record that will serve as a bulwark against collective accountability. In the first annual report of the ICTY, its President, Antonio Cassese defended the tribunal on this basis: "If responsibility for the appalling crimes perpetrated in the former Yugoslavia is not attributed to individuals, then whole ethnic and religious groups will be held accountable for these crimes and branded as criminals." International Tribunal for the Former Yugoslavia: First Annual Report, at 11, U.N. Doc. IT/68 (28 July 1994), cited in Akhavan, Justice in The Hague, supra note 25, at 766; Neier, supra note 4, at 45 (advocating that ICTY trials are "crucial" to breaking the cycle of collective attribution of guilt); Kritz, supra note 32, at 128 ("Perhaps most importantly for purposes of long-term reconciliation, [criminal trials] . . . make the statement that specific individuals--not entire ethnic or religious or political groups-committed atrocities for which they need to be held accountable"); see also Akhavan, Justice in The Hague, supra note 25, at 766 (linking the truth telling function of tribunals with social reconstruction by noting that "the recognition of truth through testimony is an irreplaceable remedy and a powerful catharsis that will contribute to deterrence by discouraging acts of vengeance and retaliation)." 
absence of individual accountability, the fear is that the entire group of those in whose name atrocities were committed will be deemed collectively accountable. Dwight MacDonald conceives of collective guilt as "a Hegelian statist approach in which individuals lack will, thought, and conscience except as these are united in the 'organic totality' of the state. ${ }^{\prime 88}$ As a result, proponents of this view assert that since everyone is guilty then no one is. Consequently collective guilt absolves everyone of responsibility for past wrongdoing. ${ }^{89}$

Finally, individual accountability enables a society to construct a new national narrative that will help forge civic unity in the aftermath of mass violence. Popular demonization of the societal group held responsible for the violence is replaced with stigmatization of the political and military leaders who planned the atrocities. ${ }^{90}$ Further, the process of public differentiation between those who ordered criminal actions and those in whose name these actions were taken is thought to be critical to social healing. The former leaders, who imposed bloodshed and brought shame on the community, are removed from public life, while those remaining are the "good" citizens who can begin to rebuild the country. Thus criminal trials not only have the practical effect of purging the criminal leadership from public life, but perhaps equally important, such trials serve as a purification ritual of the body politic. ${ }^{91}$

88. Neier, supra note 4, at 45 citing Dwight Macoonald, Memoirs of a Revolutionist 60 (1957).

89. Thus, Macdonald warns that the absence of individual accountability actually increases the likelihood of further violations. "They did not commit rape, torture, or murder on their own and cannot be held individually responsible as they were mere bit players in a historical drama. The absence of a sense of responsibility, of course, makes it far easier for them to commit such crimes." Id. Yet, as Hannah Arendt observed, it is the nature of the "administrative mass murder" directed by the Nazi regime that implicated the whole population which defied the paradigm of justice since "[w] here all are guilty, nobody in the last analysis can be judged." Hannah Arendt, Organized Guilt and Universal Responsibility, in Essars in Understanding: 1930-1954, 121, 126 (Jerome Kohn ed., 1994).

90. Michel Feher has characterized this argument as one of the tenants of "purists" who assert that successor regimes seeking to establish a democracy are required to prosecute past violators. Trials are part of a necessary political struggle the emerging government must wage successfully to defeat the political agenda that led to the past terror. Feher, supra note 38, at 329; Akhavan, supra note 79, at 9 (ad hoc tribunals have "helped marginalize nationalist political leaders" in Bosnia and Rwanda); see also Malmud-Coti, supra note 58, at 81 (criminal trials, in particular of the highest leaders implicated, expresses state disapproval of the intellectual authors and their policies and "dilutes any suspicion of continuity" between regimes).

91. However, some transitional justice scholars have criticized individualized guilt for the manner in which it can divert attention from the responsibility of third party actors. For example, Teitel points out that holding individual Bosnian Serbs accountable for the massacre at Srebrenica deflects potential criticism of the role the international community played in the mass killing. And in particular, the question of potential legal liability is not academic since the massacre took place in a UN safe haven and 
This conceptualization of how individual criminal trials contribute to reconciliation raises several concerns. First, the vocabulary of "reconciliation" and "healing" is based primarily upon theological and medical models. The reliance upon these models, to the exclusion of alternative perspectives, artificially constricts the frame of reference to examine processes of social repair. In fact, there are very little data regarding the ways in which communities rebuild in the aftermath of mass violence and even less about the contributions of justice to that process. In addition, what reconciliation means at an individual level is poorly understood. Despite this lack of data, the purported link between trials and reconciliation has solidified into articles of faith that guide policy decisions in the international arena. ${ }^{92}$

The Study reveals that this prevailing paradigm is not uniformly shared among the various national groups that are the intended beneficiaries of the ICTY. Further, the variance in attitude appears influenced by the dominant narrative in a national group about that group's wartime experiences. ${ }^{93}$ While Bosniak legal professionals subscribe to the belief that international prosecution of war criminals will alleviate social discord, many Bosnian Croat and Bosnian Serb participants felt that trials were irrelevant to social repair. ${ }^{94}$ The responses of these legal professionals suggest that they did not accept the ICTY as a legitimate institution capable of rendering impartial judgments. Instead of being "convinced" that war crimes were perpetrated in their name by the opinions issued by the Tribunal, participants felt free to disregard any aspect of the judicial "record" that did not conform to their perspective on the "truth" of what happened during the war. ${ }^{95}$ Contrary to

international criminal liability extends to acts of omission of those with political authority. Teitel, Bringing the Messiah Through the Law, supra note 19, at 185-86. Michel Feher and Teitel share a different critique of individualized guilt. Feher argues that by focusing on individual perpetrators, the ICTY draws attention to their actions as singular wrongdoers, "at the expense of the political project that they embodied." Thus, Feher cautions Tribunal judges to reject this constraint to avoid "contribut[ing] to the efforts deployed by Western governments in order to obfuscate the political nature of the Bosnian and Rwandan conflicts." Feher, supra note 38, at 337; Teitel, Bringing the Messiah Through the Law, supra note 19, at 184-86.

92. See IGNATIEF, supra note 2, at 184-90. Ignatieff critically examines the choreographed links scholars and human rights advocates make between truth, justice, and reconciliation. Adherence to scripted national identities, fortified by propaganda and other tools of state myth making, may lead citizens to reject the "truth" as determined by international trials. Only when each side to a civil war is able to admit and acknowledge the death it caused, will there be a basis for communities to recover. For a "script" of how former enemies can be reconciled see Robert Meister, Forgiving and Forgetting: Lincoln and the Politics of National Recovery, in HUMAN RIGHTS IN POLITICAL Transitions, supra note $2,135$.

93. Interview Study, supra note 20 , at 149.

94. Id.

95. Id. at 149-51. 
the predictions of transitional justice theorists, the historical record produced by the ICTY is not engendering a sense of contrition or shame among members of national groups whose forces committed atrocities. Rather, the record is a useful foil in the hands of political propagandists to solidify a sense that their national group is a misunderstood or unacknowledged victim of the conflict. ${ }^{96}$ Thus, the perspective of Study participants leads us to question the validity of the assumptions about the contribution that the ICTY makes to social healing.

Furthermore, the argument that individualizing guilt forms the foundation for reconciliation rests on the implicit assumption that holding a people accountable for direct or indirect involvement with or passive acquiescence to the crimes committed inhibits the possibility for rebuilding a nation. Once again, there are no data to support this assertion. The proposition that if everyone is guilty then no one is guilty, ignores the possibility that holding everyone responsible for past atrocities may force a nation to come to terms with its past as well as to lay the groundwork for true reconciliation. In addition, another consequence of this logic is that when guilt is attributed to specific persons, then individuals and groups are offered the opportunity to rationalize or deny their own responsibility for crimes committed in their name. MacDonald's statement notwithstanding, there is a large body of literature that reveals the complexity of how individuals respond in situations that enable violence. ${ }^{97}$

\section{B. Questions Raised by Conventional Justifications}

The conventional conception of the appropriate response to mass violence places criminal trials at the center of the process of social reconstruction. This elevation of the significance of trials claims too much and too little for the contribution that legal processes can make to rebuilding society. The assumption that holding individuals accountable for atrocities alleviates despair, provides closure, assists in creating and strengthening democratic institutions and promotes community rebuilding overstates the results that trials can achieve. ${ }^{98}$ However, a singular focus on trials as the agent that drives social repair ignores the necessity to attend to and support concomitant social processes that can act in synthesis to effect societal change.

The Study indicates that attitudes toward international criminal trials are

96. Id. at 149 .

97. See infra $\S$ II.

98. A small number of commentators are beginning to question these assumptions. See Aman, supra note 59; Minow, supra note 2, at 49-51; Drumbl, supra note 26. 
mediated by external factors, including political parties, personal loss of status, proximity to conflict, and identification with and need for acknowledgment of one's national group as a victim. ${ }^{99}$ With regard to topics touching on the war, the attitudes of participants mirrored the position advocated by the dominant political parties of the individual's national group. ${ }^{100}$ We did not attempt to determine whether the attitudes of individuals created or were themselves a product of the public positions advocated by the dominant political parties. Nevertheless, the lack of public discussion that questions or contradicts assumptions and thinking of nationalist parties limits the opportunity for the international trial record to be accepted as authoritative.

Proximity to conflict exerts a powerful influence on how strongly an individual perceives the need for criminal accountability for war crimes. Those who lived in areas exposed to fighting named individuals they held accountable for the war and war crimes as well as specific events for which international prosecutions were needed. ${ }^{101}$ Those removed from the violence placed a higher priority on postwar economic development. ${ }^{102}$ Thus, only a portion of participants who directly were exposed to fighting recognized the link between international criminal trials and reconciliation.

While the need for international criminal trials was articulated most strongly by those more directly and personally affected by the war, all participants identified with the experiences of their national group during the conflict as victims. ${ }^{103}$ Thus, while a participant may acknowledge that atrocities were committed by forces fighting in the name of that individual's national group, the participants speak about the need for international criminal prosecutions exclusively in terms of accountability for crimes committed against members of the national group with which the speaker identifies. ${ }^{104}$ In other words, legal professionals do not acknowledge directly the suffering inflicted by forces fighting in their name. Thus, on this topic, national group identity appears to be more salient that professional identity.

The differing priorities for national recovery and the identification with one's national group as a victim of the war combine to contest the assumptions of transitional justice scholars regarding the nature and scope of the contribution of international criminal trials to national repair. The need to identify one's national group as the principal victim of the conflict challenges the theory that criminal trials promote social healing by

99. Interview Study, supra note 20 , at $126,146-51$.

100. Id. at 147 .

101. Id. at 126.

102. Id.

103. Id. at 147 .

104. Id. at $147-48$. 
documenting and acknowledging the atrocities of the past. We suggest that bystanders often do not accept the record of the war publicized by ICTY trials and see the ICTY prosecutions as proof of its failure to understand and accurately reflect the experience of their national group. Rather than conform their views to the Tribunal's verdicts, bystanders point to divergences between the "truth" as they "know" it and as reflected in the ICTY record. If the need for acknowledgment of victimization overwhelms the ability to recognize and condemn the horrors perpetrated by one's national group, then criminal trials will achieve only partial success, at best.

The Study also supports our thesis that the emphasis on criminal trials as the primary international response to mass violence does not respond to the needs of many for social repair. For example, for some, economic development may exert a greater impact than legal accountability on their willingness to live together. ${ }^{105}$ Given the belief among many transitional justice scholars that one goal of criminal trials is to promote reconciliation, then our evidence that the relationship between international trials and social reconstruction is not uniformly shared should lead to a reexamination of the role of international criminal trials in promoting social repair.

It is as if one were to try to understand the effect of dropping a stone in a still lake by focusing only on the impact of the stone and ignoring the ripples it creates. Truth commissions have traditionally represented an attempt to focus on the ripples without using a stone. ${ }^{106}$ We thereafter ask the question what alternative mechanisms exist that will enhance the effectiveness of trials and the contributions of truth commissions. If trials are to achieve the goal of contributing to social reconstruction, they must be considered one part of a larger process in which additional incentives for community rebuilding are developed.

\section{COLLECTIVE AND INDIVIDUAL RESPONSIBILITY}

We begin this section by examining the assumption that criminal trials for mass violence contribute to social reconstruction by eliminating collective guilt. Transitional justice scholars and human rights activists frequently ground their understanding of this goal in the book by philosopher Karl Jaspers, On the Question of German Guilt. ${ }^{107}$ Jaspers, writing in Germany in

105. Id. at 150 .

106. The TRC attempted to retain the "stone" by reserving the possibility of criminal trials for those individuals who did not apply for or were denied amnesty. However the focus of the TRC on healing left little room for the development of structural processes in the society that would enhance the goal of the TRC for reconciliation. Its focus was on a different stone.

107. JASPERS, supra note 1. 
the immediate aftermath of World War II, articulated a typology of guilt intended to provide a framework for understanding the range of responsibility and accountability of German individuals and the German people for the criminal acts committed by the state during the National Socialist era.

On the issue of collective guilt, while Jaspers believes that: "It clearly makes sense to hold all citizens of a country liable for the results of actions taken by their state," 108 this is limited to political guilt and applies equally to those who opposed the defeated government. On the other hand, he notes that criminal acts are always carried out by individuals and thus only individuals can be held criminally liable. He raises the question of collective moral guilt and rejects the concept because

there is no such thing as a national character extending to every single member of a nation. . . . One cannot make an individual out of a people. A people cannot perish heroically, cannot be a criminal, cannot act morally or immorally; only its individuals can do so.... The categorical judgment of a people is always unjust. It presupposes a false substantialization and results in the debasement of the human being as a individual. ${ }^{109}$

We suggest that while this focus on individual autonomy is understandable it leaves no room for those social processes that collectively influence thinking and behavior. As noted in the Study, the end result has been that in periods of collective violence, the focus on individual crimes has been used by many to claim collective innocence. The assumption that individual agency is the primary determinant of behavior is open to question. Further, the forces that engulf a society and destroy its integrity are complex and can be addressed only by attending to the synchrony of influences that converge to initiate the chaos.

In this section, we examine how behavior is influenced by the presence and actions of others, particularly in the context of mass or group activity. We suggest that while the legal system focuses on individual behavior and addresses issues of motivation or criminal intent, it lacks the capacity to address the consequences of the many individual acts that characterize genocide or ethnic cleansing where participants are swept up in group violence. In the phenomenon of mass atrocities, some individuals may commit violent criminal acts; they may participate in torture or killing. Others may loot abandoned homes or seize the property of those who have fled. Still others may limit their participation to taunting or throwing stones, firing from their jobs those of different ethnicities or forcing neighbors to commit degrading acts. Finally, many profit in the black market from ethnic

108. Id. at 39 .

109. Id. at 41 . 
cleansing and war at the expense of those who left and often, of those who remain. Yet, in practice the legal paradigm is limited to punishing only a few select individuals who carried out the most egregious acts or ordered their followers to do so. ${ }^{110}$ The vast majority of those who participated in a less overtly violent manner are able to reframe their actions in ways that excuse their activity.

As Judith Shklar has noted, the law defines and limits its purview to rules, accountability, and punishment. ${ }^{11}$ The social forces and psychological dimensions that characterize mass violence are of little relevance in the legal paradigm. We see two consequences to limiting response to legal intervention. First, there is no societal challenge to the many people who became swept up in the violence either actively or by passive acquiescence thereby relieving most of the population of even moral responsibility for the violence. Second, social reconstruction is hampered by neglecting to address the social phenomena that sabotage individual will during periods of collective violence. These consequences raise the possibility for communities to develop local and national myths often framed around collective victimization or innocence. ${ }^{112}$

Although we do not believe that people are automatons blindly following the orders of others, we do contend that, under certain circumstances, individual agency is superceded by other influences that profoundly determine what actions an individual may take. Further, these influences are usually beyond the awareness of individuals. This raises the question of whether or how they can be held responsible for their actions. We will not explore in this article the implications for criminal liability of how social factors influence volition, intent, and agency. ${ }^{113}$ However, we question the assumption of the primacy of individual agency by integrating concepts gleaned from community psychology, social psychology, sociology, and genocide studies. We find evidence to support the proposition that there is a communal engagement with mass violence and this dimension is not addressed by criminal trials. Thus, we begin with an examination of the

110. See infra note 18. One consequence of this focus is that relatively little attention is paid to documenting and addressing the opportunistic crimes and mistreatment that individuals commit in contexts of war and mass violence. Nonetheless, the impact on communities of these actions may profoundly influence individuals' experience of the conflict.

111. Judith N. SxLar, Lecalism 1-28 (1964).

112. One example is the case of Jedwabne, Poland, where, in 1941, the Gentile half of the village murdered the other half, killing 1,600 jewish men, women, and children. Yet, the memorial erected to the victims attributed the massacre to the Nazis. JAN GROSS, Neighbors: the Destruction of the Jewish Community in Jedwabne, Poland (2001).

113. For example while not current practice, evidence of the impact of social forces might be considered in determining criminal liability or punishment. 
processes by which communities descend into mass violence to challenge the assumption that collective guilt, reframed as collective responsibility, should be avoided, and that individualizing guilt though criminal trials is key to social repair.

\section{A. Individuals in Group Contexts: The Contributions of Social Psychology to Understanding Behavior}

We are intrigued by the question of how individuals turn on their neighbors and how communities become engulfed in violence that destroys their social institutions and quality of life. In order to address this issue, we turn to an examination of how individuals behave in group situations as illustrated in the laboratories of social psychologists. We look at experiments that attempt to determine why individuals conform to group behavior as well as those which seek to explain why individuals remain passive in the face of threats to others. While these experiments strongly suggest the influence of social factors in determining individual behavior, scientists are unable to locate the specific nexus at which an individual will be pushed to action or withdraw from participation. Nevertheless the power of social forces to shape behavior raises provocative questions about accountability and thus deserves sustained examination.

\section{Individuals and Collective Violence}

There has long been debate about whether people act as individuals in crowd situations. Whether it is crowds of screaming adolescents at a rock concert, protesters at a nuclear weapons plant, or genocidaires in Rwanda, we ask how much a person's behavior is a reflection of something unique to the social context, the crowd. Shirley Jackson's short story, The Lottery vividly captures the frenzy of crowd behavior as villagers stone to death the lottery winner because that is the tradition of the town-good folk acting in ways that reflect the community's acceptance of behavior that is at variance with the regularities that define the social norm. ${ }^{114}$ This story vividly illustrates two phenomena: (1) that individuals may act to breach normative behavior in a crowd situation, and (2) that in these situations there is community sanction to shift the norms. These behaviors have been studied

114. Shirley Jackson, The Lottery, in THE LOTERY 291 (1949). Shirley Jackson's classic and chilling tale describes an annual rite in a small town where someone is chosen by lottery to be stoned to death. By winning the lottery, they are condemned to die at the hands of their neighbors. No explanation is offered for this ritual except tradition. 
widely in situations of mass violence, in particular within the field of social psychology.

The earliest significant work in this area was published in 1895 , by a French sociologist Gustav Le Bon. His unique book La Psychologie des Foules (The Crowd: A Study of the Popular Mind) has had a significant impact in social psychology because it raised provocative and frightening questions about the autonomy of human beings. Le Bon was fascinated by the violent protests that were part of French history and began to examine the factors that contributed to these events.

Under given circumstances, and only under those circumstances, an agglomeration of men presents new characteristics very different from those of the individuals composing it. . . Whoever be the individuals that compose it, however like or unlike be their mode of life, their occupations, their character or their intelligence, the fact that they have been transformed into a crowd puts them in possession of a sort of collective mind which makes them feel, think, and act in a manner quite different from that in which each individual of them would feel, think, and act were he in a state of isolation. ${ }^{115}$

Le Bon postulates about the influence of anonymity, contagion (the behavior of an individual(s) in a group context can spread like an infectious disease), and suggestibility (the vulnerability of an individual to model behavior based upon immediate observation) as determining factors in how individuals act in a crowd. ${ }^{116}$ Further, he suggests that crowds contribute to an absence of responsibility or impunity on the part of individuals. ${ }^{117}$ Through affirmation, repetition-both of which have been demonstrated to be effective components of social learning theory ${ }^{118}$-and contagion, crowds can be encouraged to act for good or evil. Le Bon's theory of crowds

115. Gustave Le Bon, The Crowd: A Study of the Popular Mind 23 (1960). Le Bon, a physician, attempted to develop a psychological explanation for crowd behavior. He noted the leveling effect that crowds have on those who are part of them. He postulated that in mass situations individuals undergo a transformation and primitive irrational elements emerge that allow them to behave in ways that might shock them if they were alone. The work was criticized later because of the notion of a "collective mind."

116. Id. at 30-31.

117. Id. at 32 .

118. Albert Bandura et al., Disinhibition of Aggression Through Diffusion of Responsibility and Dehumanization of Victims, 9 J. Res. Personaluty 253 (1975). Bandura and colleagues find that both dehumanization and lessening of personal responsibility enhance aggressiveness but dehumanization is a more significant disinhibitor. Humanizing the targets of punitive action can counteract this process. Lyn Lawrence and Kenneth McLeroy describe Bandura's theory of self-efficacy and note the critical importance of the individual's belief that she can carry out a specific behavior. The theory connects knowledge to action since belief that one can do something precedes the actual attempt. Lyn Lawrence \& Kenneth R. McLeroy, Self-efficacy and Health Education, 56 J. SCH. Health 317 (1986). 
raised the distinctly uncomfortable question of whether human beings are always in control of their actions, particularly in the context of collective events.

This book illuminates important issues that would be tested ultimately in the laboratories of social psychologists in the next century. Social psychologist Stanley Milgram's classic experiments on obedience to authority challenged conventional assumptions of the influence of internalized systems of morality on individual behavior. ${ }^{119}$ In a laboratory situation, community volunteers in a deception experiment thought that they were giving electroshocks at increasing voltage to subjects even while these subjects were clearly communicating suffering. The volunteers were exquisitely sensitive to the authority of the experimenter. More than sixty percent of volunteers continued to shock the subjects even into the extreme or final ranges when clear warnings of danger were posted. Varying conditions of the experiment suggested that absence of experimenter or presence of another disobedient colleague would influence behavior. Milgram's experiments clearly illustrate how, under certain conditions, individuals abandon their own ideas of right or wrong in order to meet their perceptions of an authority's expectations of their behavior. Further, in the presence of an ally who reinforces the subject's own moral and ethical standards, the individual is enabled to resist the power of the authority. While subject to many critiques ranging from unethical deception to their generalizability beyond the laboratory, work of other scholars raised similar concerns.

Professor S.E. Asch experimentally demonstrated the power of conformity in group situations. ${ }^{120}$ An individual was placed in a group where the task was to match one of three lines to a line of a certain length. All but the subject were instructed to select one of the incorrect lines and the subject was placed in such a way that the individual heard most of the other answers before his turn. Contrary to the facts, a large number of subjects (about one third) went along with the group rather than assert their own beliefs. The presence of one other individual who reported accurately undermined the power of the majority. If the support was withdrawn, there was a reversal of independent judgments. Asch concluded that the effects of conformity are responsive both to group characteristics as well as individual ones. In other words, behavior in a group context reflects the influence of the individual's personality and history as well as the influence of group process.

119. Stanley Milgram, Obedience to Authority: An Experimental View (1997).

120. S.E. Asch, Effects of Group Pressure Upon the Modification and Distortion of Judgements, in Groups, Leadership, and Men: Research in Human Relations 177 (Harold Guetzkow ed., 1951). Asch's experiments show the powerful effect of a unanimous (pre-instructed) majority in inducing an individual to conform to blatantly false judgments. 
The power of social context to determine behavior was further illustrated by Professor Philip Zimbardo's notable prison experiment. ${ }^{121}$ In 1973, Zimbardo placed a group of male college students in a simulated prison and assigned them roles as guards or prisoners. In a very short period of time (the experiment was terminated after six days), the major identity of the participants became that of the role they played. As the authors note:

[W] witnessed a sample of normal healthy American college students fractionate into a group of prison guards who seemed to derive pleasure from insulting, threatening, humiliating and dehumanizing their peers--those who by chance selection had been assigned to the "prisoner" role. The typical prisoner syndrome was one of passivity, dependency, depression, helplessness, and self-deprecation. ${ }^{122}$

In this experiment, we again see that social settings and group processes may significantly influence behavior.

Three other sets of experiments reinforce these findings. Professor Albert Bandura and colleagues conducted a complex series of laboratory experiments in which subjects were asked to administer electroshock. ${ }^{123}$ They found that aggressiveness increased in situations of lessened personal responsibility or where the recipients of the shocks are dehumanized. Bandura notes that "subjects behaved more punitively when responsibility was obscured by a collective instrumentality," that is, where decisions to shock were shared among the group. ${ }^{124} \mathrm{He}$ suggests that anonymity allows behaviors which normally an individual would suppress. Further, his findings suggest that dehumanizing the objects of aggression has an even more powerful effect in promoting aggressive behavior than diffusion of responsibility.

Professor Edward Diener and colleagues also conducted studies of aggression. ${ }^{125}$ They demonstrated through several laboratory experiments that individuals increased aggressive behavior under situations of diffused responsibility and rationalization. In addition, when subjects viewed a video of aggressive behavior they were more likely to act in an aggressive

121. Craig Haney, Curtis Banks \& Philip Zimbardo, Interpersonal Dynamics in a Simulated Prison, 1 Int'L J. Crim. \& Penologr 69 (1973).

122. Id. at 89 .

123. Bandura et al., supra note 118 .

124. Id. at 266.

125. Edward Diener et al., Effects of Altered Responsibility, Cognitive Set, and Modeling on Physical Aggression and Deindividuation, 32 J. Personality \& Soc. Psychol. 328 (1975). These authors found that disinhibiting factors such as lowering responsibility or modeling aggression can enhance physical aggression. Further, this increased aggression is not necessarily accompanied by a deindividuated internal state characterized by diminished self-awareness, decreased attention to setting, and depersonalization of the victim. Subjects were very aware of their behavior when aggressive. 
manner. Thus, seeing others act violently cued aggression. Subjects reported that they were unaware of how they were influenced by a variety of cues, however, they were capable of reporting their behavior during the experiment. This suggests that although behaviors unconsciously may be influenced by social cues, individuals nonetheless are aware of what they are doing. This raises questions about the nature of volitional activity in a situation of mass violence.

Finally, in a 1986 experiment, Professors Wim H.J. Meeus and Quinten A.W. Raaijmakers tested the Milgram paradigm by defining aggression differently. ${ }^{126}$ These scientists felt that the administration of electroshocks bore little resemblance to the decisions individuals make in everyday life. Consequently, they redefined aggression in terms of "psychological-administrative violence." ${ }^{\prime 27}$ Meeus and Raaijmakers tested this theory in a series of experiments in which subjects knowingly provided negative feedback to job applicants taking a test that would determine whether or not they successfully received a job offer. More than ninety percent of subjects obediently carried out the task despite the fact that their behavior would, so they thought, jeopardize the subjects' job prospects.

The laboratory experiments of these social psychologists attempted to test the assumptions and conclusions about individuals and collective behavior made by Gustav Le Bon. These experiments provide chilling evidence that indeed the conventional paradigm of individual autonomy is challenged in group situations. The early experiments were carried out primarily with male subjects, however, the Meeus and Raaijmakers Study included both males and females with similar results and Milgram also reported no gender differences as well.

Hewstone and Cairns in their provocative chapter "Social Psychology and Intergroup Conflict," draw on works that clearly illustrate how individual behavior changes in in-group settings. ${ }^{128}$ They describe a shift from

126. Wim H.J. Meeus \& Quinten A.W. Raaijmakers, Administrative Obedience: Carrying Out Orders to Use Psychological-Administrative Violence, 16 Eur. J. Soc. PsychOl. 311 (1986). In order to test Milgram's paradigm with an action that was more in line with everyday Western life, the authors set up an experiment in which the subjects are required to disturb a job applicant as she takes a test that will determine future employment. More than 90 percent of the subjects followed the orders.

127. Id. at 312 .

128. Miles Hewstone \& Ed Cairns, Social Psychology and Intergroup Conflict, in ETHNOPOLTICAL Warfare: Causes, Consequences, and Possible Solutions 319 (Daniel Chirot \& Martin E.P. Seligman eds., 2001). The chapter examines prejudice and discrimination and offers a review of several social-psychological theories of intergroup conflict. They note that studies indicate that close friendships across ethnic groups do not inhibit acts of atrocity in mass violence situations. Further, they look at how individuals change in group situations and offer suggestions for reducing intergroup conflict. They cite several important studies such as R. Brown \& J.C. Turner, Interpersonal and Intergroup 
that of a personal to a social identity where "in-group favoritism replaces self-favoritism." 129 Essentially, they describe a phenomenon where one's sense of what is important in determining action becomes subsumed in the values, standards and expectations of the group. Group membership becomes the controlling influence. They also cite the work of Schopler and Insko which provides significant evidence that "groups are more competitive and aggressive than individuals." 130

While at this point, behavioral scientists cannot explain why any particular individual will behave in a specific manner, as a whole, we can say that group or social determinants influence behavior. In addition, in these situations individuals may not be aware of those social influences that shape their behavior. The experiments we have cited suggest that a confluence of social influences is critical in determining behavioral outcomes. These influences include such factors as diffusion of responsibility, ${ }^{131}$ power of authority, ${ }^{132}$ dehumanization of others, ${ }^{133}$ the presence of allies, and the condition of anonymity. ${ }^{134}$ Further, group identity is a powerful force that promotes a shift in allegiance from self to group. ${ }^{135}$ Thus, there is evidence that groups behave in ways that are unique to the group as a separate entity; they are not merely a sum of the behaviors of the individual participants. Although other social psychologists have critiqued this work by noting primarily the difficulty in generalizing from the laboratory to the real world, ${ }^{136}$ the consistency with which these influences emerge suggests that this work is relevant to inquiries about individual accountability for mass violence. A possible limitation to these studies is that they primarily were carried out in Western populations. How these results might differ in various cultures, especially those that believe in collective responsibility, raises interesting questions yet to be explored. ${ }^{137}$

Behavior, in Intergroup Behavior, 33-65 (J.C. Turner \& H. Giles eds., 1981); J.C. Turner, M.A. Hoge et al., Rediscovering the Social Group: A Self-Categorization Theory (1987); J. Schopler \& C.A. Insko, The Discontinuity Effect in Interpersonal and Intergroup Relations: Generality and Mediation, 3 Euro. Rev. Sociol. 121 (W. Stroebe \& M. Hewstone eds., 1992).

129. Hewstone \& Cairns, supra note 128 , at 324.

130. Id.

131. See infra notes 119,125 , and accompanying text.

132. See infra note 119 and accompanying text.

133. See infra notes 118,123 , and accompanying text.

134. See infra note 120 and accompanying text.

135. See infra notes $128-30$ and accompanying text.

136. Charles Helm \& Mario Morelli, Stanley Milgram and the Obedience Experiment: Authority, Legitimacy, and Human Action, 7 POL. TheORY 321 (1979).

137. See Ann-Belinda S. Preis, Human Rights as Cultural Practice: An Anthropological Critique, 18 Hum. RIs. Q. 292, 286 (1996) (the issue of valuing the group/collective over the individual is seen in many cultures and has been described as a risk to the human rights regime). Thus, alternate conceptions of accountability may permeate the entire 
What is the significance of these experiments for social reconstruction? Because the criminal justice system addresses only individual accountability for criminalized acts, the evidence from social psychologists forces us to rethink the question of collective responsibility. Further, their work suggests that communal actions may require communal responses. In mass violence, as we have noted previously, individuals participate in a myriad of ways, ranging from killing to quiescence. Rebuilding a society requires communities to acknowledge the full range of acts in which their members participated for reconciliation to be a realizable possibility. If this acknowledgment does not occur, history may be rewritten, as we saw in the former Yugoslavia after World War $\mathrm{II}^{138}$ - a development that may have laid the foundation for the events of the 1990s. Criminal trials only address the responsibility and guilt of a small number of individuals and thus can offer only one of many avenues to social repair.

legal system. For example, one commentator has noted that China lacks a tradition of "legalism" as conceived of in Western legal traditions. Instead of a "rule of law" implemented by the state, conflicts are resolved by the family "working through connections (guanxi) with each other and with the Chinese bureaucracy." Joseph $W$. Dellapenna, Symposium: East Asian Approaches to Human Rights. Selected Panelists from the 1995 Annual Meeting of the American Society of International Law: The Role of Legal Rhetoric in the Failure of Democratic Change in China, 2 BufF. J. INT'L L. 231, 238 (1995). To date relatively little attention has been paid to the cultural contexts in which criminal accountability for mass atrocities is contemplated. For example, a former press officer for His Holiness the Dalai Lama, the spiritual and temporal leader of Tibet, recounts that in audiences with followers, His Holiness frequently recounted an exchange he had with a former monk of Namgyal Monastery whom he had known from Tibet and who was in Chinese prison for over 20 years. His Holiness asked the monk what was the greatest threat to his life in prison, and the old monk said that the biggest threat he faced in prison was "losing compassion to the Chinese." His Holiness would tell his listeners: "Isn't this wonderful?" and underscore this incident as an example of the genuine practice of religion. E-mail from Tsering Tashi, Office of Tibet, London, to Eva Herzer, former President of the International Lawyers Committee for Tibet (6 Dec. 2001, 21:48:12 B0600) (on file with authors). Thus it seems reasonable to question whether religious practicing Tibetans would embrace criminal trials of Chinese leaders responsible for repression and torture of Tibetans. Such a challenge has been posed in Sierra Leone, where international, governmental, and nongovernmental children's advocates have expressed concern over the proposed criminal prosecutions of child combatants in Sierra Leone, noting that prosecutions contradict "Sierra Leone's cultural values of forgiveness and healing." Further, they felt that such prosecutions would jeopardize the legitimacy of the special tribunal in the eyes of local communities by ignoring local values of a child as an integral channel of peace and reconciliation. Ilene Cohn, The Protection of Children and the Quest for Truth and Justice in Sierra Leone, 55 J. INT'L Aff. 1, 11 (2001).

138. Journalist Roy Gutman, who reported extensively from the Balkans during the war, observes that Tito's decision to suppress history was his most significant weakness. He notes: "No objective history has been written of the Yugoslav civil war, which coincided with World War II . . . there are no agreed-upon facts except that at least one million Yugoslavs died in the war, most within the Serb and Croat communities." Roy Gutman, A Witness to Genocide xxi (1993). See generally Noel Malcolm, Bosnia: A Short History 193-212 (1994). 


\section{The Bystander Phenomenon}

We turn now to another critical question. We have reviewed the literature regarding how people may be influenced to commit aggressive acts by several unconscious processes. But when do they turn away? Under what conditions do people observing violence fail to intervene to save the victims of an attack? Our concern arises from our attempt to understand how mass violence can erupt in neighborhoods where longstanding relationships give way to persecution and murder. We assume that in most episodes of mass violence only a fraction of the population commits criminal acts. Another fraction risks its personal security to speak out against the evil or actively intervenes. In the midst of these two extremes lies large numbers of individuals who do "nothing." In this section, we look to the laboratories of social psychologists to inform our understanding of the bystander phenomenon. In section III we will examine how attention to this problem must be incorporated into efforts at social repair.

Driven by the lack of response of thirty-eight witnesses to the brutal attack on Kitty Genovese in Queens, New York, in 1964, two social psychologists, Bibb Latané and John Darley, conducted an extensive series of experiments to analyze the process of active intervention. ${ }^{139}$ These studies led to a surprising set of conclusions. Latané and Darley found that societal norms of altruistic behavior rarely come into play in urgent situations in which active intervention is warranted. In fact, they conclude that the presence of others will usually stifle the impulse to help. If the situation is ambiguous, the uncertainty may make the individual more vulnerable to inaction and more susceptible to social influence. They conclude that people are more constrained in public because of a fear of making a mistake, appearing inept, or being seen as over-emotional. Finally, they note:

As each person in an ambiguous and potentially dangerous situation looks to others to gauge their reactions, each may be falsely led to believe that others are not concerned, and consequently to be less concerned himself. This state of pluralistic ignorance may make each member of the group less likely to act. ... ${ }^{140}$

139. Bibb Latane \& John Darley, The Unresponsive Bystander: Why Doesn't He Help? (1970). The victim, Kitty Genovese, was attacked at 3:00 a.m. as she came home from work. Although the attack lasted over a half an hour and thirty-eight of her neighbors heard her cries, not one came to her aid; no one even called the police. These studies suggest that greater numbers of people involved in an activity inhibit any single individual from taking moral responsibility. Groups thus can deter individual action especially if others are passive.

140. Id. at 42 . 
Consequently, fear inhibits action and produces conformity. Further, if others are in the area, there is a diffusion of responsibility for taking action. ${ }^{141}$

As a result of these experiments, Latané and Darley concluded that a series of steps must occur for someone to intervene actively in an emergent situation: the individual must notice that something is happening, interpret it as an emergency, and finally, take personal responsibility for alleviating the situation. These steps may be varied by factors that mediate between thought and behavior, such as confusion, time for decision-making, and ambivalence to action. However, the presence of others clearly modifies this process. Latané and Darley's work suggests that over and above personal responsibility, groups as a collective deter action, especially if the others present remain passive. In all these cases, individuals stated that they were unaware that social situations modified their behavior. These findings are supported by the work of psychologist Ervin Staub. He has differentiated the bystander phenomenon into two principal groups: (1) those who remain passive in the face of individual mistreatment, and (2) those who respond passively in the midst of societal persecution. ${ }^{142}$ Primarily derived from Holocaust studies, he believes that most bystanders remain passive due to the influence of societal and cultural factors. However, ultimately, we are better at describing and theorizing than achieving a full understanding of this phenomenon. ${ }^{143}$

141. Id.

142. Ervin Staub, Transforming the Bystanders: Altruism, Caring, and Social Responsibility, in Genocide Watch 162 (Helen Fein ed., 1992). In this chapter, Staub examines the roots of altruistic behavior and the barriers to action that may be reflected in the passivity of bystanders.

143. There is a third group of actors in situations of mass violence-those who act to protect, hide, or otherwise assist members of the group that have been targeted for murder, expulsion, or other forms of violence. Svetlana Broz has written about those in exYugoslavia who often spontaneously reached out to help their neighbors or even strangers. Sverlana Broz, Good People in Evil Times (1999). The concept of "righteous gentile" emerged from the ashes of the Holocaust to describe those who assisted the Jews. We assume that actions such as these derive from individual motivation and may be less a product of group behavior. What distinguishes people who act out of courage is not readily apparent. Ervin Staub discusses three motives for altruistic behavior-a prosocial value orientation, i.e., a motivation to assist others and to be concerned about their welfare; second, a moral-rule orientation, acting in accordance with rules of morality that define how to behave towards others; and finally, empathy, the ability to place oneself in the shoes of others. Staub, supra note 142, at 164. While this research has gathered data from helping situations, whether these conclusions apply in a time of genocide or ethnic cleansing is unclear. Of course, this third group raises important questions about individual accountability since not all succumb to violence or sink into quiescence. This rescuer phenomenon introduces an additional complexity to an understanding of individual behavior in group contexts. 


\section{Implications from Social Psychology for Understanding Collective Violence}

These experiments graphically illustrate the power of the collective to influence behavior. They indicate that people may engage in aggressive behavior under the influence of social settings and that this behavior may differ from that which they usually would demonstrate. Further, the data raise questions about the role of perceived authority, social support or abandonment, perception of others as less than human, and the contribution of conformity to action. Although this work is carried out in laboratory situations, and the role of state authority may differ, these experiments raise critical questions about how crowds act and react and about the power of social processes to influence individuals to action or inaction at levels of awareness that may be beyond the conscious state.

In addition, these experiments indicate that social settings influence the motivation of individuals to take personal responsibility for their actions. The lack of awareness of social cues may contribute to their denial of the opportunity to intervene. Another consequence of this lack of awareness is that bystanders may identify as victims rather than acknowledge complicity in the adverse events, allowing bystanders to rationalize their passivity. We observed this phenomenon of victimhood in our study of Bosnian judges and prosecutors. ${ }^{144}$ This process also raises a critical question-if individuals are influenced by others not to act, even if they are unaware of this influence, should they be relieved of responsibility for their inactivity? We argue that by individualizing guilt in criminal trials, the legal paradigm reinforces the use of denial as a psychological defense mechanism within the population at large and supports the bystanders' claim that they did nothing wrong, that is collective innocence. ${ }^{145}$

We believe that this issue must be addressed outside a court of law if social repair is to become a reality. Since they "did nothing wrong," bystanders have no criminal liability. But as we have seen, doing "nothing" is doing "something." Thus, addressing the bystander issue becomes an additional critical element in the process of social reconstruction.

\section{Societal Violence and Genocide}

We now turn from the social psychologists' laboratories to consider the writings of social scientists who have examined societal violence from the

144. Interview Study, supra note 20 , at 147.

145. The Western legal approach of individual accountability may be even more problematic in those societies where collective responsibility is the norm and mass action may be expected in those situations where families or groups perceive threat. 
broader perspectives of political, cultural, social and historical factors that have contributed to mass violence. This body of literature also points out that the phenomenon of mass violence involves complex influences that reflect state and interstate politics and policies. Since the Holocaust, social scientists have sought to grapple with and make sense of the horrors of that human catastrophe as well as other episodes of mass destruction. ${ }^{146}$ Most of this literature centers on variations in definition, causality, differing perspectives on the utility of the United Nations Genocide Convention, and narrowly focused disciplinary perspectives. ${ }^{147}$ Eric Markussen and Damir Mirkovic observed that genocide studies remains a discipline in search of definition but find its principal contribution is not in examining specific cases of genocide, but rather studying the nature of mass killing itself. ${ }^{148}$

One work that attempts such an understanding is Frank Chalk and Kurt Jonassohn's The History and Sociology of Genocide. ${ }^{149}$ These authors suggest two preconditions to genocide: (1) dehumanization of a targeted group, and (2) a strong central authority that is heavily bureaucratized. In searching for the roots of genocide scholars have offered analyses that

146. See Neviti Sanford \& Craig Comstock, Sanctions for Evil (1971); Robert J. Lifton, The Nazi Doctors: Medical Killing and the Psychology of Genocide (1986); Daniel J. Goldhagen, Hitler's Willing Executioners: Ordinary Germans and the Holocaust (1996); Ervin Staub, The Roots of Evil: The Oricins of Genocide and Other Group Violence (1989). These writings explore the phenomena of genocide though different lenses ranging from Lifton's study of physicians who participated in mass killings to Goldhagen's exploration of why hundreds of thousands of ordinary Germans contributed to the genocide of the Jews when many had a clear option of withdrawing their support or not participating in the atrocities.

147. Chalk and Jonassohn offer an excellent review of the issues addressed by genocide scholars in their chapter, The Conceptual Framework, see infra note 149, at 3-53.

148. Eric Markusen \& Damir Mirkovic, Understanding Genocidal Killing in the former Yugoslavia: Preliminary Observations, in Collective Violence: Harmful Behavior in Groups AND Governments 61 (Craig Summers \& Eric Markusen eds., 1999). This piece provides an excellent review of concepts of genocide with particular relevance to the former Yugoslavia.

149. Frank Chalk \& Kurt Jonassohn, The History and Sociology of Genocide: Analyses and Case Studies 29 (1990). This work reviews the major debates within the field. The authors offer a typology to help frame the analysis of the phenomenon. Based on the motives of those who commit genocide, they offer the following classification:

1. to eliminate a real or potential threat;

2. to spread terror among real or potential enemies;

3. to acquire economic wealth;

4. to implement a belief, theory, or an ideology.

Id. at 29. They acknowledge that there are other ways to explore a comparative perspective by examining what types of societies, perpetrators, victims, and groups are involved and what results are achieved. While they too suggest a definition for genocide, the importance of their contribution lies in the attempt to provide a framework that will allow scholars to assess commonalities and differences across these horrific events and further, to suggest limitations and directions for research. 
hypothesize the influence of social factors such as authorization, routinization, dehumanization, and "social death." 150 For example, David Goldhagen has argued that the long history of anti-semitism had wide and uncritical support of the German people and provided the foundation for the Naziinitiated plan to exterminate the Jewish people. ${ }^{151}$

In an attempt to understand how individuals come to support and often participate in the actions of an evil regime, sociologist Neil Smelser notes: "One of the most profound aspects of evil is that he who does the evil is typically convinced that evil is about to be done to him." ${ }^{152}$ This belief may be supported by a variety of social factors that can mobilize individuals to take particular action. For example, cultural myths may provide the rationale for persecution and violence, leading some to carry out human atrocities. ${ }^{153}$

While genocide scholars note that "collective denial" has surrounded genocides, some, like Helen Fein, Israel Charny, and others have pioneered this new interdisciplinary field of genocide studies to confront this denial. Further, they forge new methods of analysis to understand the root causes of genocide. We believe that one of the most significant contributions of this scholarship has been to alert us to the complexity that underlies genocide and to caution against a unilateral approach both to understanding and to prevention. While these scholars do not offer us a specific blueprint that inevitably leads to mass killings, their work raises the following critical question: if we do not comprehend the processes of civil destruction in a broader, ecological context, how can we identify and address the crucial aspects of civic reconstruction? ${ }^{154}$

\section{SOCIAL BREAKDOWN AND SOCIAL RECONSTRUCTION}

\section{A. Social Breakdown: Some Approaches}

In the previous section, we drew upon the work of social psychologists and genocide scholars to inform our understanding of the ways in which individuals and communities may be complicit in mass violence and yet

150. Herbert C. Kelman \& V. Lee Hamiton, Crimes of Obedience: Toward a Social Psychology of Authority and Responsibllity (1989); see also GoldhaGen, supra note 146.

151. Goldhagen, supra note 146 , at 27-128.

152. Quoted in SANFORD \& Comstock, supra note 146, at 17.

153. Udovicki, Introduction, in BURN THIS House, supra note 10, at 1-3.

154. Helen Fein, Accounting for Genocide: National Responses and Jewish Victimization During the Holocaust (1979); Helen Fein, Genocide: A Sociological Perspective, 38 CurRent Sociology 1 (1990); Israel Charny, Toward the Understanding and Prevention of Genocide (1984); Genocide: A Critical Bibliographic Review (Israel Charny ed., 1988). 
this involvement is not addressed by the dominant legal response. Yet, the cited research indicates that we must address the collective processes that created, abetted, or passively supported the violence in order for meaningful community rebuilding to occur. This problem is part of a larger issue we address here: there is no theoretical foundation that underlies the concept of social repair. There are few conceptual or pragmatic linkages between the approaches advocated by transitional justice scholars, international diplomats and representatives of NGOs, e.g., "reconciliation," "rule of law," "democratization," and "development."155 Any interventions that are designed to promote reconciliation-other than cessation of hostilitiesshould emerge from the empirical research that has provided the foundation for understanding the collective nature of violence. We suggest that in order to do so it is critical to examine the phenomenon of societal destruction or social breakdown. In this section, we offer a model to explain how response to social breakdown might reflect the component parts of the process that led to the violence.

How do we understand the ways in which a society degenerates into chaos? Sociologists have offered several theories to explain this phenomenon. In a comprehensive review of sociological theories of mass violence, Bert Useem describes the evolving debate in the field as to causality. $\mathrm{He}$ reviews the dominant construct of breakdown theory-a theory that locates the causes of mass violence in the loss of restraining power by society's mechanisms of social control. ${ }^{156}$ In essence, Useem articulates a theoretical

155. Some recent examination in this area has begun, yet generally such attempts bring together experts from different disciplines and institutions rather than set forth an integrated framework of analysis. See Symposium, State Reconstruction After Civil Conflict, 95 Am. J. Int'L L. 1 (2001); The Aspen Institute, Honoring Human Rights From Peace To Justice (1998). Or, scholars advocate a contextual approach to post-conflict accountability efforts. See Drumbl, supra note 26, at 1225 (the particular methods to achieve social reconstruction should be guided by the social geography of particular postgenocidal society); Minow, supra note 2, at 4 ("[T]he variety of circumstances for each nation, and indeed each person, must inflect and inform purposes in dealing with the past and methods that work or can even be tried"); Kritz, supra note 32, at 152 (noting that there can be no single model for accountability mechanisms and each country "will need to find the specific approach or combination of mechanisms that will best help it achieve the optimal level of justice and reconciliation."). While we support a particularized approach to social repair, we believe that greater attention must be paid to and by the various institutions engaged in reconstruction efforts to achieve a synergistic effect of their efforts.

156. Bert Useem, Breakdown Theories of Collective Action, 24 ANN. Rev. Soc. 215 (1998). This is a review article that summarizes the twentieth century evolution of sociological theories to explain the occurrence of mass violence. The author counters critiques of breakdown theory by arguing the importance of differentiating between routine collective action such as strikes and non-routine violent action such as mass violence. He discusses as well other important contemporary theoretical approaches such as resource mobilization theory, prospect theory, and cultural theory. 
framework for Le Bon's 1895 description of crowd behavior. Another approach, termed resource mobilization theory espoused by William Gamson, Charles Tilly, and others suggests that violence occurs when groups pursue their interests by utilizing their resources and solidarity to achieve their ends. ${ }^{157}$ Useem points out that while this theory may explain what is termed "routine collective action," e.g., strikes, it does not fully explain "nonroutine collective action," e.g., mass violence. Useem cites a study by Anthony Oberschall of the disintegration of Bosnia-Herzegovina to suggest that the fighting erupted due to a combination of institutional breakdown - caused not by impersonal processes but human agency-and the formation of ethnically-based solidarity groups. ${ }^{158}$ Thus, the phenomenon of breakdown may reflect several processes that meld to destroy the social fabric.

Other scholars have updated breakdown theory by integrating additional theoretical approaches. ${ }^{159}$ David Snow and colleagues have synthesized prospect theory-which asserts that individuals make decisions based on rational choice-with cultural theory-which introduces the concept of the "quotidian," i.e., everyday life that we all take for granted. This integrated theory suggests that: Social breakdown both (a) generates losses which, in turn, are experienced as highly salient deprivations (prospect theory), and (b) undercuts actors' confidence that their accustomed routines can continue to provide a satisfactory future (cultural theory). ${ }^{160}$ This sequence of perceptions leads to heightened resentment and ultimately, to violence. ${ }^{161}$

157. Id. at 216, citing Willam A. Gamson, The Strategy of Social Protest (1975) (Wadsworth edition 1990); Charles Tilly, From Mobilization to Revolution (1978).

158. Id. at 226, citing Anthony Oberschall, Bosnia: Civil War, Ethnic Cleansing, and Atrocities, Address at Mellon Seminar, New Nationalism, New Identities, New Perspectives, Duke Univ. (1997).

159. Useem, supra note 154, at 227, citing David Snow et al., Disrupting the Quotidian: Reconceptualizing the Relationship Between Breakdown and the Emergence of Collective Action, 3 Mobiuzation 1 (1998).

160. Id. Social breakdown can be understood as both an acute as well as long term process. While peace may bring an end to active conflict, nonetheless, reconstitution of the social framework may occur over an extended period of time. Thus, as we saw in the Study, Bosnian judges and prosecutors interviewed four years following the Dayton Peace Accord continued to mourn the loss of their status and felt that there was little they could do to change their fate. Interview Study, supra note 20, at 116-18.

161. Writing from the vantage point of political science, Susan Woodward has documented the economic and social collapse of the former Yugoslavia that occurred following the death of President Tito. Susan L. Woodward, Balkan Tragedv: Chaos and Dissolution After THE COLD WAR (1995). Though writing from another discipline, her perspective illustrates breakdown theory. She observes that as the good life deteriorated, the federal system pulled apart and through the manipulation of nationalist leaders, national group identity assumed an increased salience. This re-emerging social identity and enhanced solidarity led to increasing resentment against the state institutions. Against this backdrop, the 
Based on our study and consideration of a half-century of scholarship in sociology, we propose a schematic model to illustrate this process which we refer to as "social breakdown." Our description of social breakdown, although similar to the concept of breakdown theory is not intended as an explanatory model but merely to encapsulate the processes that emerge as a state descends into chaos. ${ }^{162}$ This perspective sets the stage for an examination of how the rebuilding of a social system may be supported. While it draws on our experience in the context of the former Yugoslavia, we aver that this model has wider applicability.

Figure 1 illustrates our model of the process of social breakdown. It depicts how the various segments of a society interact in the process of breakdown. We suggest a three-stage model of social breakdown. In the first stage, social breakdown, a society undergoes a sequence of destabilizing events leading to a second stage characterized by war or mass violence. In the third stage, cessation of the violence is achieved through diplomatic, military, global, or regional interventions.

Although the causal factors that initiate the process of social breakdown may vary, in the first stage, economic or political instability is often at the root of its evolution. A cycle of resistance and government response leading to extremism and persecution often results in episodes of violence and repression. Isolated violence escalates, leading to stage two, in which the country becomes engulfed by war or mass violence. In this stage, the violence destroys the physical, economic, and social infrastructure creating mass dislocation and undermining societal order and stability. As constraints on appropriate behavior are loosened, war crimes and mass human rights violations may become the visible byproducts of breakdown. The final stage is demarcated by the termination of armed conflict. Frequently this occurs when the international community becomes engaged actively in diplomatic or military interventions to restore and maintain peace.

Republics of Slovenia and Croatia separated from Yugoslavia, and a violent backlash began, led by the Serb leadership. Shortly thereafter, the Republic of Bosnia-Herzegovina fractured along national group lines and descended into a bloody three-year conflict.

162. We acknowledge the rich debates within sociology regarding the roots of mass violence. However, we leave to one side further consideration of causality. Instead we employ a descriptive model in order to analyze the ecological relationships which inform an understanding of necessary interventions toward social reconstruction. 
FIGURE 1

The Process of Social Breakdown (Modified from Toole, 1997)

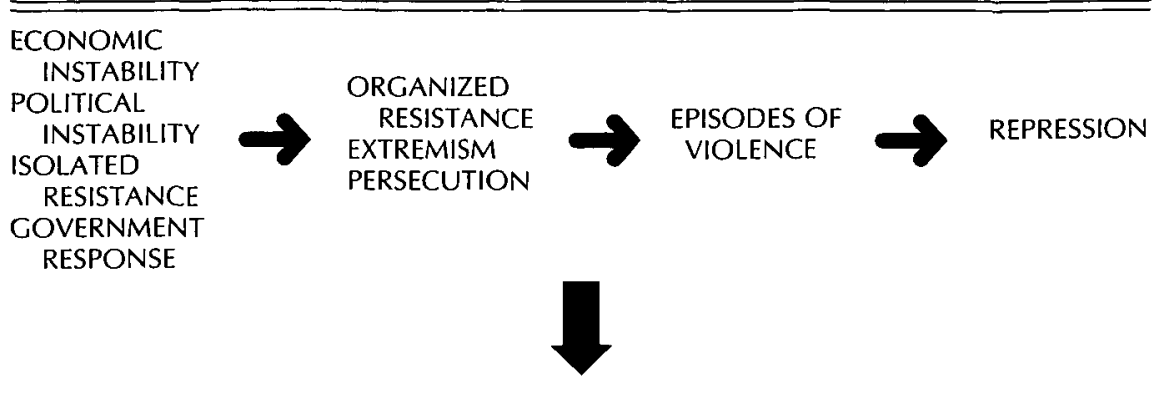

WAR OR MASS VIOLENCE

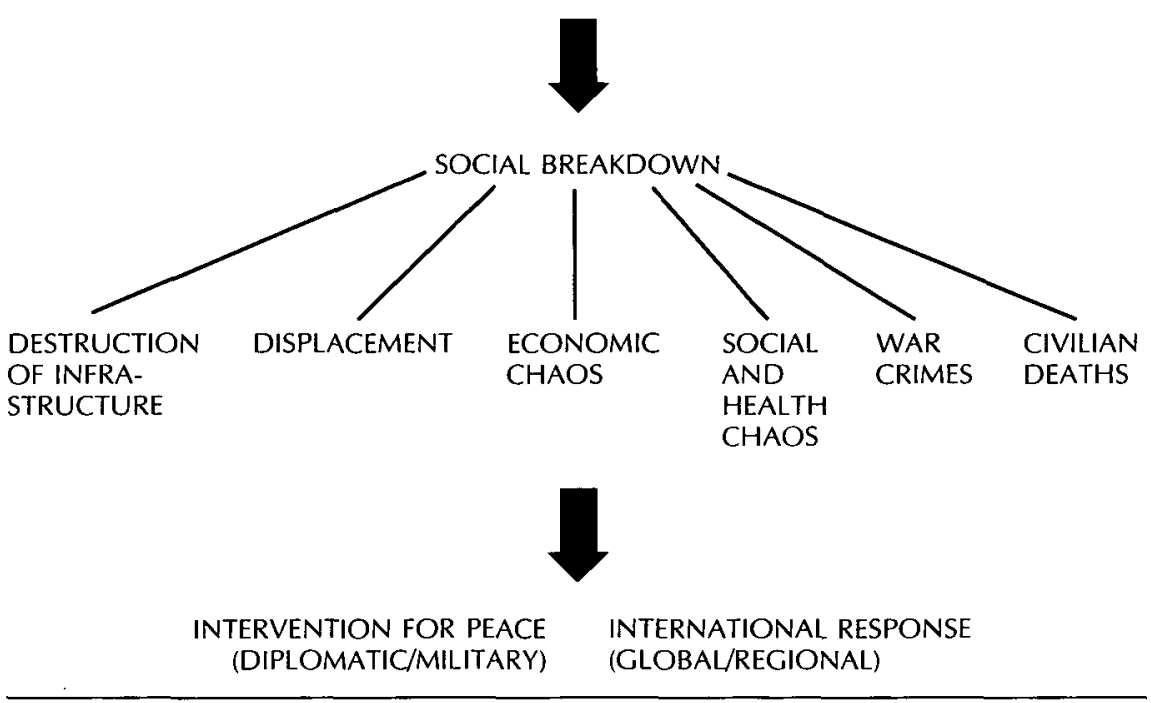

\section{B. Social Reconstruction: An Ecological Model}

\section{The Ecological Paradigm}

Given the complexity of social systems it is not surprising that any one approach to understanding the descent into violence or to rectifying and returning a country to peace, is doomed to failure without a consideration of the multiplicity of influences that determine those events. We suggest that an "ecological paradigm" developed by community psychology scholars is essential to understanding how collective violence occurs, how to assign responsibility for violent acts, and finally, the steps that must be undertaken 
to repair and rebuild broken ties, broken communities, and broken lives. The power of an ecological perspective lies in its ability to provide a framework to interpret events that arise from multiple causes and in multiple institutions and multiple dimensions.

The ecological paradigm offers a theoretical model to understand how social systems change. Community psychologist James Kelly and colleagues ${ }^{163}$ have described the critical interrelationships that underlie social change by pointing out how reciprocal and mutual dependencies between and among individuals, institutions, community and societal groupings must be attended to in order to understand and influence social change. They draw on the work of Professor Robert Rappaport who notes: "the ecosystem concept itself is a vital element in the construction, maintenance, and reconstruction of the webs of life upon which, by whatever name we call them, we are absolutely dependent."164 They note the importance of structures and processes in facilitating social change.

Ecological theory postulates that analysis of a social system must attend to (1) a thorough understanding of the social, economic and political settings that make up the system; (2) the ways in which transactions are carried out across the boundaries of the components of the system as well as how these boundaries are established, maintained and modified; and (3) the resource potentials of the system components and the key individuals who influence policy and action. ${ }^{165}$ Critically, an ecological approach emphasizes that change in any one part of a system causes reactions throughout. ${ }^{166}$ Consequently, systemic change must anticipate these reverberations by anticipating these responses and addressing how interdependencies affected by a change strategy are going to be manifest. It is apparent that piecemeal approaches that involve separate agencies attempting to change different components of a system are doomed to failure in the absence of an overall and coordinated strategy that is based on an ecological analysis. We suggest that this method of examination offers a blueprint for social reconstruction. ${ }^{167}$ We have seen how social breakdown rapidly engages

163. James Kelly et al., Understanding and Changing Social Systems: An Ecological View, in HandBook of Community Psrcholocr 133 (Julian Rappaport \& Edward Seidman eds., 1999). The Handbook is a compendium of the most salient thinking in the field as of 1999. Chapters on concepts, social systems, prevention, intervention, empowerment, and other dimensions of community psychology illustrate the breadth of its vision.

164. Id. at 133, citing Robert Rappaport, Ecosystems, Populations, and People, in THE Ecosystem Approach in Anthropology: From Concept to Practice 69 (E.F. Morgan ed., 1990).

165. See Kelly et al., supra note 163.

166. See id.

167. While the ecological paradigm could be used to analyze the process of social breakdown, social breakdown theory by itself-because of its lack of an explanatory framework for the complex interactions between social institutions and their effects on 
multiple actors and societal institutions in a chain of violence. Ecological theory and its application suggests that, if attention is directed to those structures and processes that can build rather than destroy, calm may be restored.

The question then, is what are the processes that contribute to the maintenance of peace and reconstruction of society? We propose a model that incorporates the salience of contemporary breakdown theory. Thus we argue that comprehensive intervention must address three primary features of the individual's relationship to social breakdown: (1) perception of loss, (2) loss of mastery and control over one's destiny, and (3) relationship to the violence, whether as a participant, a bystander, or a rescuer. Because individuals perceive losses as occurring in multiple dimensions, we argue that social reconstruction must comprise interventions that engage these various dimensions. We illustrate this model in Figure 2.

\section{Components of an Ecological Model for Social Reconstruction}

If the goal of transformation in the aftermath of mass violence is social reconstruction, we must ask what is social reconstruction? The term reflects recognition of the fact that mass violence may not destroy only the physical infrastructure of a country. One of the consequences of mass violence is that the social fabric of a society is torn apart. Despite the fact that the prior social arrangements may not have guaranteed adequate respect and protection of human rights, there was a measure of stability. Yet the destabilization brought about by mass violence is so profound that the old ways are no longer viable options. Thus social and institutional arrangements in this new era may not necessarily duplicate those prevailing during the pre-conflict period. ${ }^{168}$ Rather than reconstruction, peace and stability may require construction of new societal structures and relationships. We suggest that social reconstruction consists of the following elements: (1) justice; (2) democracy; ${ }^{169}$ (3) economic prosperity and transformation; and (4) reconciliation. The last element, reconciliation, is a process that takes place on an individual level and may not be mandated, but rather interventions may lay the foundation for reconciliation to occur in the

individuals and communities-does not deepen our understanding of the necessary steps to achieve social repair.

168. These new changes may reflect a genuine commitment to a free and equitable society or merely the hollow rhetoric of a victorious regime.

169. We believe that democracy can be reflected in many types of institutional arrangements. However, the governmental structures must satisfy minimal requirements including transparency, mechanisms of accountability, and citizen participation. These are critical elements of a well-functioning society where conflicts are resolved in a nonviolent manner and human rights are promoted and protected. 
FIGURE 2

Ecological Model of Response to Social Breakdown

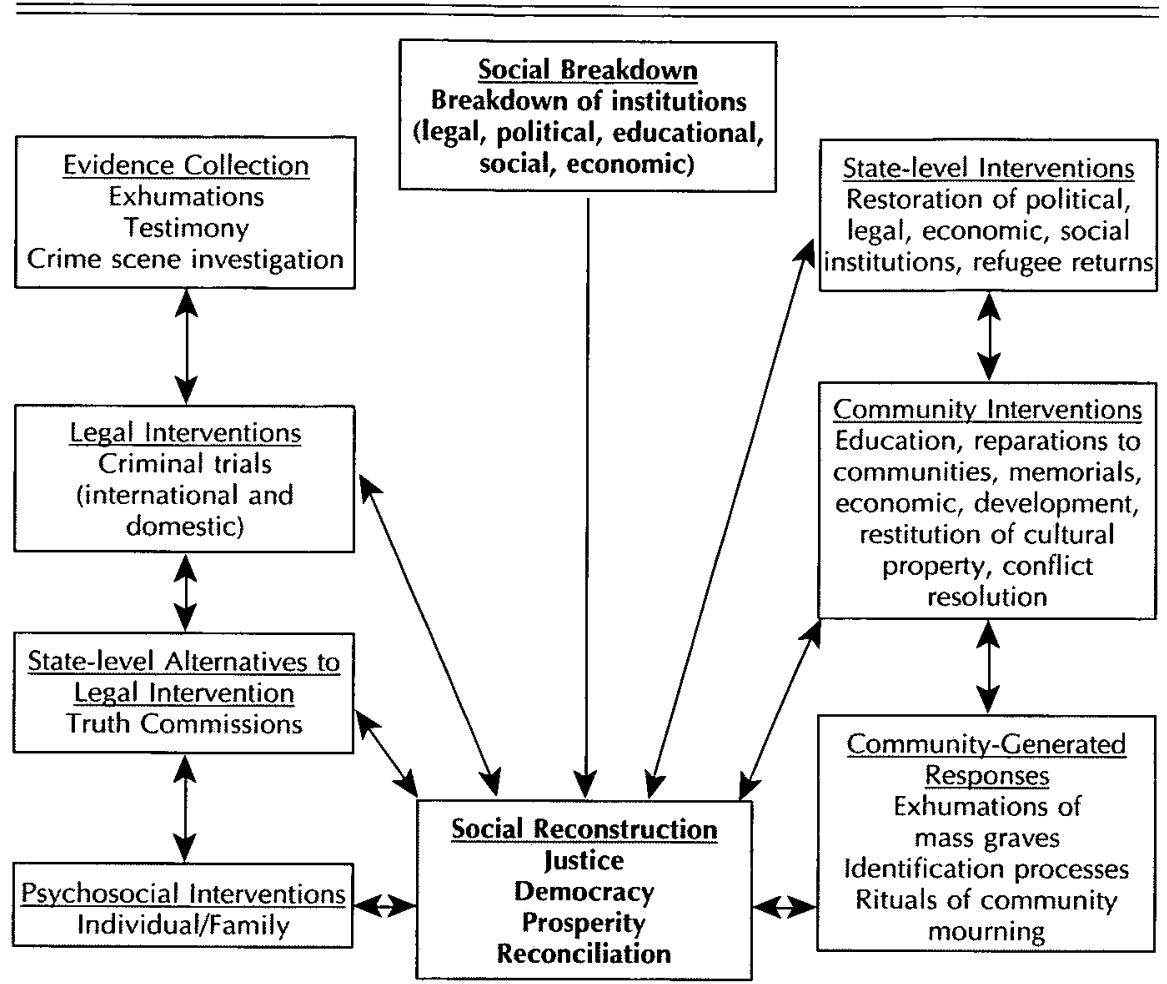

future, if at all. In the short-term, co-existence may be sufficient to enable the other elements of social reconstruction to take hold.

We recognize that these elements are not static but dynamic processes that interact and build upon each other to achieve social repair. In order for social reconstruction to adhere, we assert that multiple interventions must act in synergy to address the various perceptions of loss, the need for restoration of control and acceptance of one's role in the initiation of and participation in the conflict. Psychologist Abraham Maslow proposed a theory of a hierarchy of needs that underlies human motivation. ${ }^{170}$ Essentially, he offered a pyramidal model of human needs in which the necessities for survival such as food, water, sleep, etc. are at the bottom, and

170. Abraham Maslow, Motivation and Personality 35-41 (1954). 
then in successive order, safety, love, esteem, and finally, self-actualization at the top of the pyramid. ${ }^{171}$ Reconciliation-which requires empathy, forgiveness, and altruism-draws on higher order manifestations of need that cannot be addressed until the more basic needs are satisfied. An ecological model addresses this dynamic by assuring that attention is paid to these multiple levels of unsatisfied need both at an individual and community level.

We suggest therefore that the following interventions are critical components of a carefully orchestrated attempt at social repair: (1) statelevel interventions; (2) criminal trials (national or international); (3) commissions of historical record (truth commissions); (4) individual and/or family psycho-social support; (5) externally-driven community interventions; and (6) community-based responses.

Each type of intervention contributes uniquely to the reversal of one or more of the features of social breakdown. Under an ecological framework the synergistic effects of interventions at multiple points in a system lead to social reconstruction. We have suggested that responding to the perception of loss and control due to one's role and acceptance of one's role in the violence are necessary components of the repair process. However, because each individual is uniquely situated vis-à-vis each component and further, the needs for repair vary based on experience, no single intervention can aspire to address the needs of a diverse population. Thus, the process of social reconstruction must attend to restoration of basic security while at the same time building a consensus about historical record, punishing perpetrators, honoring the memory of the missing or dead, rebuilding infrastructure so as to enable commerce, and allowing communities to resurrect or build a framework for cooperation among the different groups. Any single goal, such as consensus about the historical record, must respond to the individual's relationship to the violence, whether as victim, perpetrator, bystander, or rescuer.

Each of the boxes in Figure 2 represents a particular target of change. State-level interventions attend to such issues as refugee returns, restoration of government, structures, as well as legal and economic reform. Trials individualize guilt and exact punishment. Both truth commissions and trials may enable a nationwide consensus on the events as they unfolded. Psychological interventions may be necessary to address the effects of trauma on individuals and families. Community interventions such as memorials, rebuilding of cultural institutions, and the teaching of communitybased conflict management strategies may originate from outside the

171. Id. at $97-104$. 
community but they must be supplemented by community-generated responses such as public rituals of mourning to restore some sense of agency. There must be public acknowledgment of the losses that people have experienced and recognition of the victimization that many feel. In order to respond to the myth of collective innocence, education projects in schools and other arenas must address the question of community shame so that those who participated either actively or by acquiescence cannot escape their moral responsibility for the violence that shredded the fabric of community.

As with any ecological perspective, interventions in each of these arenas will trigger responses elsewhere in the system. Ongoing monitoring assures that responses are attended to and feedback may shift the focus from one area to another while the overall strategy is pursued.

In this section we examine the contribution that each of these components may make to social reconstruction.

\section{a. State-level Interventions}

State-level interventions occur at the nexus of international efforts and the actions of the successor governments to restore peace and stability. For example, in the context of the Balkan conflagration, the Dayton Accords initiated a series of structural transformations and institutionalized an international presence to direct and sustain the rebuilding of Bosnia and Herzegovina. ${ }^{172}$ These types of interventions may offer international resources-military, police, legal consultation, and civil administration-to assist the state during its transition from conflict to democracy. ${ }^{173}$ These interventions assume many forms. The international community may be involved in governance, legal reform, election monitoring, policing, adjudicating property claims, and implementing accountability measures within civil structures. By restoring peace and a measure of stability, state-level interventions address the issues of perception of loss as well as offering the necessary preconditions for restoration of a sense of control to community members.

In some countries, like Rwanda, the international community serves primarily in an advisory role. ${ }^{174}$ In other contexts, like East Timor, the UN

172. General Framework Agreement for Peace in Bosnia and Herzegovina, initiated in Dayton, Ohio, 21 Nov. 1995, signed in Paris, 14 Dec. 1995.

173. Krishna Kumar, The Nature and Focus of International Assistance for Rebuilding Wartorn Societies, in Rebuilding Societies After Civil War: Critical Roles for Iniernational. Assistance [hereinafter Rebuilding Societies] 1-38 (Krishna Kumar ed., 1997).

174. The initial UN mandate for its mission in Rwanda was to monitor the terms of the cease fire, assist with mine clearance, monitor repatriation of Rwandese refugees, assist with 
has assumed sole responsibility for all aspects of governance. ${ }^{175}$ In many situations, such as Northern Ireland and Nigeria, the UN has no meaningful presence. In these instances, successor governments may become the central architects of state building and may or may not rely on financial assistance from international donors to effect systemic change.

While these interventions may be critical in the initial phases of peace building, they tend to be "top down," with pre-existing expectations as to the form and content of desired outcomes. ${ }^{176}$ Over time, the vulnerabilities of this approach become more apparent. Frequently, political, economic, and social priorities for international programs are developed under intense time-pressures and often without adequate consultation with relevant stakeholders. As a result, well-intentioned interventions may be perceived by the intended beneficiaries as irrelevant or even demeaning. ${ }^{177}$ Although an important aspect of social reconstruction, the limitations of these interventions must be addressed in other ways.

\section{b. Criminal Trials}

The principal contribution of criminal trials is to afford a measure of individual accountability for atrocities committed. Criminal trials fulfill the expectation within many societies that those who commit egregious acts deserve punishment.

In social breakdown there are two sets of perpetrators: (1) political and military leaders who planned and directed the criminal acts, and (2) the individual soldiers, militia members, and civilians who carried out the

coordination of humanitarian assistance, and investigate non-compliance with peace agreement as well as activities of police. S.C. Res. 872, U.N. SCOR, 48 th Sess., Res. \& Dec. at 102, U.N. Doc. S/RES/872 (1993).

175. The UN mandate for its mission in East Timor established that the agency would be "endowed with overall responsibility for the administration of East Timor and will be empowered to exercise all legislative and executive authority, including the administration of justice." S.C. Res. 1272, U.N. SCOR, 4057th mtg., U.N. Doc. S/RES/1272 (1999), available at <http://www.un.org/peace/etimor/docs/9931277E.htm> (visited 25 Mar. 2002); Question of East Timor, U.N. Secretary-General, U.N. Doc. S/1999/862 (1999), available at <http://www.un.org/peace/etimor/docs/9923160e.htm> (visited 25 Mar. 2002). In Kosovo, the UN mandate includes extensive intervention in domestic affairs, but stops short of assuming full responsibility for civil administration of the country. S.C. Res. 1244, U.N. SCOR, 4011 th mtg., U.N. Doc. S/RES/1244 (1999).

176. Kumar's edited volume contains chapters related to elections, rule of law, government structures, etc. Rebuiloinc Societes, supra note 173. These, of course, are critical dimensions of rebuilding societies. We suggest that much of the impetus for change comes from without and that ownership by the citizens of the country is not always apparent. For an impassioned account of the vulnerabilities of these processes, see Graham Hancock, Lords of Poverty (1989).

177. Interview Study, supra note 20, at 139-40. 
atrocities. Retributive justice mandates that both sets must be held accountable. ${ }^{178}$ The collection of evidence, including exhumation of mass graves, constitutes a critical element of this process.

Criminal trials have the potential to address all three features of social breakdown. For victims, trials acknowledge their loss and punish the perpetrators for the harm inflicted. ${ }^{179}$ For some, this may enable a sense of acceptance of their loss and facilitate a positive change in perception about their future. Community members similarly may benefit by neutralizing the intellectual authors of the conflict. Finally, the trial record permits unindicted perpetrators and bystanders to confront their complicity in the atrocities. ${ }^{180}$

However, as we have noted previously trials have limitations. Of particular relevance here, is that while there may be widespread acceptance of the importance of putting the leadership in the dock, for many victims it is important to hold accountable those who directly committed criminal acts against them. ${ }^{181}$ It may not be practicable for an international or domestic criminal justice system to conduct trials for all those accused of war crimes or gross human rights violations during a conflict. Nevertheless it may be possible for social reconstruction to take place through a combination of alternative strategies to address the problem of the unindicted perpetrators. Perhaps the most significant contribution of criminal trials is that they are an active intervention by the state to reverse the process of social breakdown by establishing a boundary within which individuals may be held responsible for their behavior toward their fellow citizens. ${ }^{182}$

\section{c. State-level Alternatives to Legal Interventions}

While trials focus on individual actions and victims, truth commissionsthe primary alternative to criminal prosecutions-center their analyses at the level of the state and society. ${ }^{183}$ Although structured in many different

178. See infra notes 53-59 and accompanying text.

179. See infra § I.A.1.-2.

180. See Neier, supra note 4, at 51. We emphasize the potential of criminal trials to achieve these goals and note that their relative success depends on a variety of factors. See infra notes 90,91 , and accompanying text.

181. Interview with Eric Stover, Director, Human Rights Center, University of California, Berkeley, 23 Mar. 2000. Stover based these remarks on the preliminary results of a study of witnesses who have testified before the ICTY.

182. We consider this to hold true for state cooperation with international trials as well. In some countries the infrastructure may be so decimated that national trials are not a practicable option, nevertheless state cooperation with international trials can signal to citizens that new regime is committed to punishing the perpetrators.

183. The South African Truth and Reconciliation Commission was a notable exception to this general practice. The TRC was empowered to grant amnesty to individual perpetrators only if they made a full disclosure of their deeds and expressed remorse for their actions. 
ways, truth commissions offer victims, witnesses and, in some instances, perpetrators the opportunity to tell their stories to help create an historical record. As Priscilla Hayner has noted, a significant advantage of truth commissions lies in their ability to delineate a broad perspective on causes and patterns of the violence.

Yet despite the more limited legal powers of truth commissions, their broader mandate to focus on a pattern of events, including the causes and consequences of the political violence, allows them to go much further in their investigations and conclusions than is generally possible in any trial of individual perpetrators. Indeed, the breadth and flexibility of a truth commission are its strength. ${ }^{184}$

Truth commissions respond to the societal need to know what caused the violence, how it was carried out including who and what segments of society were implicated and what were the consequences of these events. While they may name individual wrongdoers, truth commissions focus on a comprehensive examination of the structural and institutional actors and their contribution to social breakdown. Because truth commissions are sponsored by the international community or by the state, in theory they enjoy a moral authority and political legitimacy that enables the reports of these bodies to form the foundation for a new narrative about the past. Thus, these investigative institutions are poised to replace past denials about repression, massacres, and genocide with the truth of these horrors. These commissions address the issues of loss, participation, and restoration of control at a societal level by articulating the events and naming those responsible. ${ }^{185}$ They represent a good faith effort on the part of the state to address what went wrong and to build a viable and secure future.

The South African Truth and Reconciliation Commission ("TRC") is the best known and most carefully developed of these interventions. As a former South African Minister of Transport, Mac Maharaj commented:

See also Johnny De Lange, The Historical Context, Legal Origins and Philosophical Foundation of the South African Truth and Reconciliation Commission, in LookINC BACK, Reaching Forward 14 (Charles Villa-Vicencio \& Wilhelm Verwoerd eds., 2000).

184. Hayner, supra note 2, at 16; see Paul Von Zyl, Justice Without Punishment: Guaranteeing Human Rights in Transitional Societies, in Looking Back, REACHING ForWARD, supra note 183 , at $42-57$.

185. The mandates and practices of truth commissions vary, only a minority of truth commissions-Chad, El Salvador, and the TRC - have attributed responsibility to named individuals for egregious acts. The issue of naming names is subject to great debate; many argue that the due process rights of those named as perpetrators are violated, while others assert that the truth-telling power of the endeavor is fatally compromised without publishing the names of those responsible. See generally HAYNER, supra note 2, at $107-32$. 
We have taken the concept of justice in its broadest sense and found a formulation that meets the specific requirements of our country-a formulation that contains a strong element of restorative justice, while limiting retribution to public exposure and shame to the perpetrators, whose names and deeds are becoming known. ${ }^{186}$

Johnny De Lange notes, however, that the TRC has elements both of restorative and retributive justice since perpetrators are exposed as to identity and atrocity. ${ }^{187}$ Paul von Zyl, former Executive Secretary of the TRC, makes a strong case for a flexible approach in dealing with the legacies of the past. He notes:

Punishment for past wrongs is a very important, but not indispensable strategy in dealing with the past . . . an inflexible approach to punishment should not divert resources or distract the international community from formulating and implementing other initiatives to promote and protect human rights. ${ }^{188}$

Therefore, truth commissions may be elected by successor governments as an alternative or complement to criminal trials to address the need to assure collective memory of the atrocities. Although often criticized as a mechanism to allow perpetrators to escape with impunity, in fact, their purview is broader than justice for any individual; truth commissions aim to facilitate state repair. ${ }^{189}$

There are two important criticisms of a truth commission effort. First, unless the findings of a truth commission are linked to concrete efforts to restructure institutional arrangements and personnel who promoted or enabled structural violence, the work of a commission potentially may be undermined and its impact weakened. Furthermore, in the absence of such changes, bystanders and unindicted perpetrators may see the truth commission as a momentary abreaction at the state level and that now life may return to "normal." Second, we note that for individual victims simply telling their story likely is insufficient. Unless individuals who testify before a truth commission achieve some tangible response, e.g., reparation, they may be left with a sense of ongoing helplessness and may feel sacrificed for the sake of state stability. ${ }^{190}$

186. Quoted in De Lange, supra note 183 , at 25.

187. Id. at 23-26.

188. Von Zyl, supra note 184 , at 57.

189. Of course, as the South African TRC illustrates, an amnesty provision does not necessarily mean that perpetrators avoid trials.

190. Recompense by the state, in the form of reparations (particularly when criminal liability is not possible) assumes heightened importance and, for many victims who were impoverished by the violence, becomes a practical necessity to regain a sense of control over their destinies. 


\section{d. Psychosocial Interventions}

The ecological perspective must also take into account the needs of individuals and their families for assistance in dealing with loss, grief, and the psychological sequelae that may accompany mass violence. Psychological support may help those who have been exposed to violence to ease both the acute and chronic psychological pain. Acknowledging the individual's experience of the violence by offering psychological and pharmacological interventions can be a critical component of restoring a sense of security and control over one's life. ${ }^{191}$

Much attention has been paid to psychosocial interventions often predicated on the concept of post-traumatic stress disorder ("PTSD"). ${ }^{192}$ We caution against the assumption among many mental health professionals that psychiatric illness routinely affects a substantial proportion of a population subsequent to mass violence. While the concept of PTSD has been the subject of much debate, it is apparent that only a proportion of survivors (from 3.5 percent to 65 percent in various studies) manifest ongoing problems. ${ }^{193}$ At this point, we cannot explain the differences in prevalence of PTSD in the aftermath of mass trauma, although the studies examine populations from many cultures and experiences. ${ }^{194}$ Nevertheless, those individuals with disabling symptoms require specialized interventions. We suggest that the wholesale export of the PTSD-as a medical syndrome as well as an indicator for treatment-has resulted in therapies that may not be culturally appropriate. It is critical that societal context be considered in applying these strategies.

Furthermore, for the much larger number of survivors who do not develop psychiatric syndromes, we must consider psychosocial interventions more broadly-ranging from psycho-educational work with children in classrooms to computer or other classes for women that will enable skills

191. Psychological assistance may be appropriate for bystanders and perpetrators to come to terms with their roles in the violence. While this is controversial among those who treat torture survivors, we suggest that in periods of prolonged violence, individuals may be both victims and perpetrators. More study of this aspect of psychosocial rehabilitation is indicated.

192. Rachel Yehuda \& Alexander McFarlane, Conflict Between Current Knowledge About Post-traumatic Stress Disorder and Its Original Conceptual Basis, 152 AM. J. РsYCH. 1705 (1995).

193. Derek Silove, The Psychosocial Effects of Torture, Mass Human Rights Violations, and Refugee Trauma: Towards an Integrated Conceptual Framework, $187 \mathrm{~J}$. Nervous \& Mental Disease 201 (1999); Patrick Bracken et al., Rethinking Mental Health Work with Survivors of Wartime Violence and Refugees, 10 J. Refugfe Stud. 431 (1997).

194. SUMMERFIELD, supra note 7. 
development and possible career opportunities. ${ }^{195}$ Ultimately, these interventions must address the three issues of loss, control, and denial or shame as people try to come to terms with their roles in the violence. While much effort has been directed at individual interventions, less attention has been paid to how these fit into the overall strategies for social repair. Once again, we emphasize that multilevel interventions are necessary but coordination and coherence are key.

\section{e. Community Interventions}

Mass violence affects communities in profound ways. Therefore social repair should focus on the community as a separate unit of analysis. Responses to the recent eruptions of inter-group conflict have resulted in a variety of community-level interventions, typically initiated by international governmental organizations (IGOs) and NGOs. These well-intentioned interventions usually target various aspects of society and range from psychosocial, cultural, social, economic, to political. As noted above, these psychosocial programs may include group therapies, micro-enterprise development as well as conflict resolution programs. ${ }^{196}$ Cultural initiatives may include support for the arts, rebuilding libraries and other cultural monuments and memorializing community losses. ${ }^{197}$ Redevelopment efforts frequently focus on restoring health and social services. ${ }^{198}$ Economic renewal requires at a minimum the restoration of the physical infrastructure and perhaps wholesale economic restructuring. At the level of the community, transparency in political life coupled with shift in political power may be required to facilitate good government. ${ }^{199}$ While support for the emergence of active NGOs will assure a vibrant civic life, political restructuring may need to occur in governmental institutions as well. ${ }^{200}$ These interventions capitalize on social networks to restore voice and agency to impacted communities.

195. Inger Agger, Psychosocial Assistance During Ethnopolitical Warfare in the Former Yugoslavia, in Ethnopolitical Warfare: Causes, Consequences, and Possible Solutions 305-18 (Daniel Chirot \& Martin E.P. Seligman eds., 2001).

196. See infra notes 189-93 and accompanying text.

197. See, e.g., Kimberly A. Maynard, Rebuilding Community: Psychosocial Healing, Reintegration and Reconciliation at the Grassroots Level, in Rebulloinc Societies, supra note 173 , at $203-20$.

198. Joanna Mocrae, Dilemmas of Legitimacy, Sustainability, and Coherence: Rehabilitating the Health Sector, in Rebuiloinc Societies, supra note 173, at 183-201.

199. Kumar, supra note 173.

200. Post-conflict restructuring may be focused on establishing stable democratic structures at the state level, however the promotion of a vibrant civil society will be integral to the success of this effort. See Samuel H. Barnes, The Contribution of Democracy to Rebuilding Postconflict Societies, 95 Am. J. INT'L L. 86, 99 (2001). 
Many of these interventions do not arise from the articulated needs of community members but are based on the views of international humanitarian and development agencies and are frequently perceived as externally imposed. ${ }^{201}$ Communities may perceive these interventions as unwarranted intrusions into their way of life. Misguided interventions may create tensions and exacerbate a pre-existing sense of powerlessness.

There is another weakness to community-based interventions. As conceptualized, the current menu of programs offered to address social breakdown does not attend to the collective nature of violence. As noted earlier, scientists do not yet fully understand the reasons for collective violence, however we do know that this process confounds our understanding of individual agency and volition. Consequently, if social reconstruction is the goal of community interventions, we must begin to address those factors in the collective that led to the fragmentation and destruction of the community, even given the current imperfect state of knowledge. Acknowledging this dimension is the first step to imagining, developing, and implementing programs to repair the damage done by collective violence. In order to do so, we must increase our efforts to engage communities themselves in articulating their needs around community regeneration. Differences in culture and tradition may result in processes of community repair that are very different from the prevailing models.

\section{f. Community-Generated Responses}

One of the principal after-effects of mass violence is the powerlessness that a community as a whole experiences. Empowerment theory ${ }^{202}$ and the work of activists like Paolo Freire suggest that supporting a community in identifying and realizing its needs is the foundation for community regeneration. ${ }^{203}$ Therefore representatives of international, governmental and NGOs, humanitarian relief agencies, diplomats, and scholars should devote

201. Agger, supra note 193, at 311-12; Michael Maren, The Road to Hell: The Ravacing Effects of Foreign Aid and International Charity (1997). This book is a critical review of how foreign aid is used and international NGOs. Richard Falk, The Failures of "InterventionFrom-Above": Is There an Alternative Model for Humanitarian Intervention? 1 MFD. \& Giobal Survival 229 (1994); HanCOCK, supra note 176. Hancock offers a penetrating and even bitter critique of international aid particularly the work of multilateral agencies. He particularly criticizes the lack of acknowledgment of the voices and concerns of the people directly affected by the aid process.

202. Marc A. Zimmerman, Empowerment Theory: Psychological, Organizational and Community Levels of Analysis, in HANDBOOK OF COMmUNity PsYCHOLOGY, supra note 163, at 4363.

203. Paolo Freire, Pedagocy of the Oppressed (1970) (Myra Bergman Ramos trans., Continuum 2000). 
more attention and thought toward enabling local communities to develop and implement responses that represent their aspirations for social repair. In addition, community participation in the process of rebuilding may itself strengthen and promote its well being. These interventions, by restoring selfefficacy, may prove to be the most successful because they have the potential to engage individuals in attending to the critical factors of loss, control, and participation in the violence.

Those outside a community may expect that the result of reconstruction will entail recreating institutions and social arrangements that antedated the conflict. As we have noted, it may be that "reconstruction" in fact requires "construction" of new institutions, relations, and arrangements. The radically destabilizing effects of mass violence leave permanent scars on communities as well as on individuals that cannot be erased. As one survivor stated: "I can forgive, but I can never forget.". 204

So too, communities may never be the same. Yet the goal of social repair is to construct institutional arrangements capable of managing conflict and providing security to those living within its boundaries. ${ }^{205}$ There may be overlap between community-based interventions and those that are initiated for other purposes. The collection of evidence for use in judicial or other investigations such as truth commissions may interfere with those processes a community must attend to as part of (re)building. For instance, in the investigation of large-scale atrocities such as genocide and crimes against humanity in which tens of thousands of people may have been killed, judicial forensic experts may not give priority or have the resources to identify the remains of suspected victims found in a mass graves. Instead, forensic experts often place a greater emphasis on determining the cause and manner of death of the victims and thus help prosecutors establish a pattern linking specific perpetrators to a series of massacres. Moreover, the exhumed bodies may be collected en masse for further investigation and only subsequently returned to families after a lapse of months or even years. Therefore, these procedures do not take into account the needs of families and communities to identify, bury, and mourn their dead. Furthermore, given these limitations, in some situations there may be little or no international or national acknowledgment or support for exhuming more graves than are necessary.to satisfy the investigative priorities.

204. Weinstein \& Stover et al., supra note 36; Udovicki, BurN ThIS House, supra note 10, at 1 3, 89-90.

205. We are making a distinction between the destructive effects of mass violence on individuals and communities from the mechanisms of social repair. In other words, while mass violence affects individuals and communities, the mechanisms needed to assist individuals in rebuilding their lives may differ significantly from those needed to repair communities. 
The work of the AMANI Trust and Shari Eppel in Zimbabwe exemplifies the importance of identifying and supporting community rituals that enable repair. ${ }^{206}$ In the wake of independence, the forces of President Robert Mugabe carried out a series of massacres in Matabeleland against the supporters of his political opponent. ${ }^{207}$ The government, not surprisingly, never investigated these atrocities. Moreover, those buried in unmarked graves were left undisturbed, but not forgotten. To this day, community members report that their communities continue to be plagued by the restless and angry spirits of those who were murdered.

To alleviate this distress, the AMANI Trust initiated a program to exhume mass graves and to identify and rebury the victims. Eppel reports remarkable results from this program. For example, in one family no member had been married since the male head of the household was murdered over twenty years before. According to community tradition, the marriages could not take place until a new head of household assumed his role. This transition required the proper burial of the murdered man, who remained in an anonymous grave. In this case, exhumation and reburial led to the immediate installation of the eldest son as the head of the family. Soon thereafter, this son married, began a family and reclaimed his extended family's stature within the community. Eppel offers many similar examples. This program clearly demonstrates what can be gained by attending to the articulated needs of a suffering community.

More work needs to be done in this area. In particular, we believe that community-generated responses should be supported and further, that linkages should be forged between these efforts and the other interventions described in our ecological model. We suggest that integration of these various approaches at multiple levels (state, community, family, individual) in multiple sectors (economic, cultural, social, political) develops synergies that amplify positive effects of all programs designed to promote social reconstruction.

\section{v. CONCLUSIONS}

The question that animates this article is how does justice contribute to social reconstruction in the aftermath of mass violence. We have proposed an ecological model of response to social breakdown. This model locates

206. Shari Eppel, Healing the Dead to Transform the Living: Exhumation and Reburial in Zimbabwe (Apr. 2001) (unpublished manuscript, on file with authors).

207. Shari Eppel, Healing the Dead to Transform the Living: The Preventive Implications (Jan. 2001) (unpublished manuscript, on file with authors). 
justice in the web of possible interventions that must be addressed in order to promote social reconstruction. As indicated, a central justification for criminal trials offered by many in the international community and human rights organizations is the assumption that establishment of the rule of law and democracy is a critical component of reconciliation. In particular, advocates for war crimes trials subscribe to the belief that individual accountability is necessary to achieve this goal.

And yet, a careful review of the process of social breakdown reveals that the rapidly escalating process of group or collective violence may have its origin in strategy and planning by a select group of individuals but ultimately relies on the force of group power to achieve its ends. War crimes trials do not address the phenomenon of collective power and its influence on individuals. Since trials are responsive only to one dimension of the abuse of power, their limitations with respect to addressing the social and collective forces that lead to the violence must be recognized.

As our summary of the social science literature indicates, social forces are critical in determining aggressive behavior and hesitancy to intervene. Furthermore, trials, with their emphasis on individual accountability, offer bystanders the opportunity to rationalize inaction in preventing atrocities like ethnic cleansing or genocide. The traditional lack of attention to the issue of collective responsibility-if not accountability-is a vulnerability that may lead to future violence. This vulnerability should be addressed through specific intervention(s) that challenge bystander denial, rationalization, and feigned ignorance that explain away inaction.

As Useem notes: "Individuals inevitably offer a moral justification whenever their actions, however destructive and self-interested, violate a moral principle." ${ }^{208}$ In addition, Albert Bandura writes about "self-exonerating practices" and notes that: "What was morally unacceptable becomes, through cognitive restructuring [reframing one's thinking], a source of selfpride. ${ }^{\prime 209}$ Unless these rationalizations are addressed at a community level, the myth of collective innocence is perpetuated and social reconstruction itself becomes a process built upon false premises.

208. Useem, supra note 156, at 232, citing James Q. Wilson, The Moral Sense (1993). It is striking that those in whose name aggression was committed in Bosnia-Herzegovina evoke two justifications for the violence. The first is a belief in the "higher principle" of maintaining a unified state-either Yugoslavia or a nationalist entity. The second is a glorification of the history and tradition of the Serb people-Christians who must maintain the border of Europe against the "Muslim onslaught." Michael A. Sells, The Bridge Betrayed: Religion and Genocide in Bosnia 27-28, 29-52 (1996); Laura Silber \& Alan Little, Yucoslavia: Death of a Nation (1995); David Rieff, Slaughterhouse: Bosnia and the FAILURE OF THE WEST (1995). Rieff's angry indictment of nationalism and Western passivity illustrates how "higher" principles may result in sacrifice of innocent people.

209. Bandura et al., supra note 118 , at 254 . 
Therefore, for any society to reconstitute in a peaceful fashion, alternative interventions must be considered in synergy with war crimes trials. We are not proposing to eliminate criminal accountability as an option. However the international responses to those countries which have lived through mass violence are piecemeal. Generally interventions follow a progression from humanitarian intervention to rule of law and democratization followed by long-term economic development and perhaps, criminal trials. The multiplicity of agencies makes a coherent vision of social reconstruction difficult to achieve. Often overlooked are the voices and articulated needs of families and communities. Further, these voices, often influenced by stereotypes, propaganda, ethnic/nationalist media, and selfserving politicians, lose their ability to articulate memories of a different time when "the other" was once their neighbor. For social reconstruction to occur, the institutional actors and agencies involved must incorporate an ecological understanding of the constituent elements of social repair. Without an appreciation that any single intervention has consequences throughout the web of social arrangements, programs will operate in isolation. Thus any synergies among interventions will be happenstance rather than intended.

Of course, we must ask what the end-goals of reconstruction should be. As noted, justice is the prevailing paradigm for social repair. This is reflected in the view that retributive justice is essential-not vengeance, but justiceto achieve long-term stability. We propose an additional set of questions. First, we must also ask what justice means to a particular society or even whether there is a single answer to that question. Second, we should ask whether justice is the only or even the best form of acknowledgment of loss. Third, although democracy is a frequently-stated goal of reconstruction, we should ask as well what that term means in a particular society. Further we ask whether democracy may assume a form that is similar to or different from Western conceptions. Fourth, while prosperity usually accompanies health, well-being, and peace, we ask what is the contribution of economic investment to that process. Finally, we question whether or how any of these factors contribute to reconciliation. We suggest a fruitful inquiry is to ask how people can learn to live next to each other without killing their neighbors and what factors will contribute to peaceful coexistence. We aver that reconciliation is likely an individual act that represents a choice made based on one's ability to forgive or forget. It is not an action that the state or the international community can mandate.

We raise these questions in order to illuminate the complexities involved in social repair. While we offer no definitive answers, our ecological model provides a framework for further elaboration of the interrelationships among these factors. Because reconciliation as an objective 
for social healing enjoys widespread acceptance, we offer some observations regarding the utility of this perspective.

Adhering to a narrow view as to what is required to achieve reconciliation, the international legal community emphasizes criminal trials as the principal strategy to achieve this end. ${ }^{210}$ With the advent of the ad hoc international criminal tribunals, the aspirations for what these trials can accomplish have expanded specifically to encompass the goal of reconciliation. ${ }^{211}$ Further, as our data suggest, this phenomenon grants war crimes trials a far greater salutary effect than has ever been demonstrated.

Although criminal trials continue to set the benchmark for response to atrocities, the last twenty years have seen the evolution of truth commissions as an alternate approach, employed primarily in situations where trials are not feasible. ${ }^{212}$ As we have described, these endeavors offer a framework to intervene at a community level in at least three dimensions-creating an historical record, allocating responsibility for the structural violence, and acknowledging the pain of those who have been victimized. Proponents of truth commissions argue that in the absence of criminal trials, truth itself can serve to salve the wounds of a society fractured by violence and consequently lead to reconciliation. However, the contexts in which these are established may not always reflect the voices or needs of those most directly affected.

Disappointment may ensue, anger may result and the process of community rebuilding may be no further ahead. The relationship of these commissions to the process of reconciliation is no more apparent than that of trials. Some humility may be necessary in assessing the contributions of a truth commission to rebuilding a society. Further, these institutions reflect historical contexts and political conditions, which, while potentially positive, may not meet the needs of those who have been most victimized nor fully address the issue of societal responsibility.

Ultimately, a comprehensive community-based approach that includes the opinions and ideas of those whose lives have been most directly affected is critical. Building consensus among all stakeholders is necessary to effect the structural changes that will ensure social reconstruction. Interventions

210. This view of criminal trials is reflected by Gary Jonathan Bass's dichotomous presentation of the appropriate response to large-scale war crimes as being either justice or vengeance. While he acknowledges the limitations of criminal trials, he posits vigilantism as the only alternative to legalism. BAss, supra note 30 , at $304-10$. We suggest that this view neglects consideration of possible communal responses to mass violence as well as other modalities of intervention that attend to reversal of social breakdown without resorting to further violence. See infra $\S$ III.B.

211. See infra note 17 and accompanying text.

212. HaYNeR, supra note 2 , at 3 . 
may encompass trials or truth commissions-if the affected communities so desire-but also may include economic empowerment, early rebuilding of cultural institutions, changes in government structure (including personnel), ${ }^{213}$ reparations to communities and individuals, as well as neighborhood-based inter-group reconstruction activities. Further we suggest that international interventions should be implemented in the context of an ecological understanding of social repair.

Societal violence is a totalizing experience. Yet Jaspers observes that it is the intimate and personal nature of one's experience of mass violence that informs one's perceptions about what should happen next. ${ }^{214}$ To date, truth and justice have been the rallying cries for efforts to assist communities in (re)building in the aftermath of mass atrocities. These employ a paradigm that focuses on individuals who have been wronged (victims) and those who inflicted their wounds (perpetrators). Missing is an appreciation for the damage mass violence causes at the level of communities. Totalizing experiences necessitate totalizing responses. We return to our earlier metaphor of a stone cast in a lake. It is not enough to cast the stone; over time, we must still the ripples. With an ecological framework, we can begin to see the lake.

213. For example, Inga Markovits has chronicled the transition in the East German judiciary at the time of reunification. Inga Markovits, Last Days, 80 CAL. L.R. 55 (1992).

214. Jaspers takes up the question of the relation of the individual to National Socialism and the crimes of the state through his examination of moral guilt. JASPERS, supra note 1, at 63-73. 